\title{
The Resurrection of Field Warehousing
}

\author{
- the Booming Hungarian Field Warehousing Sector, \\ the Incomplete English Narrative and the Unexplored Field \\ Warehousing Law of the United States -
}

\author{
Tibor TAJTI (ThaYthy)(
}

\begin{abstract}
Irrespective the many secured transactions reform projects around the globe, field warehousing as a peculiar constructive pledge-based (or pledge by bailment) security device, and what it may offer especially to emerging markets, has largely escaped attention. The few international projects that devoted some attention to warehousing as a financing method were almost invariably limited to public (terminal) warehousing or have canvassed an incomplete picture about this many-faced security device.

Scholarly neglect is characteristic also to the United States (US), where field warehousing as a security device has had presumably the richest history yet has declined after the adoption of the unitary Article 9 system of the Uniform Commercial Code by the States. In new forms, adapted to the changing business needs, however, the industry has survived to date. While what is of little importance in the US, should be invaluable to reform systems, which could enormously profit from the US experiences yet by taking a look not only at contemporary but more importantly on earlier law as well.

English law, as another leading financial law system and thus a model for others, is taken a look at because it knows not about field warehousing. The conventional yet not fully explored justification is the earlier recognition of the floating charge in England compared to its kin on the other side of the Atlantic. The article counters this argument by juxtaposing not just the US but also the more recent Hungarian developments corroborating that floating securities and field warehouses are not mutually exclusive.

This seminal article aims to remedy the hinted at cognitive gaps in comparative scholarship by revisiting the pertaining US law, reflecting on the English position and uniquely juxtaposing the parallel recent Hungarian experiences with field warehousing. The heightened importance of this analysis is linked also to the continued interest in the reform of secured transactions laws (recently also in Africa and China), and the unsatisfactory economic output of such recently reformed systems as those of Central and Eastern Europe (CEE) - well reflected in the third in-depth revamping of Hungarian secured transactions law by the new Civil Code of 2013.
\end{abstract}

Keywords: field warehousing, secured transactions law reform, floating charge (lien), non-possessory security devices, policing of the collateral, escrow

Tibor Tajti, Professor of law and Director of the Doctoral (S.J.D.) Program at Central European University, Budapest, Hungary. My acknowledgements for exchanges related to this article go to Professors Hugh Beale (Warwick, UK), David Brown (Adelaide), Amy C. Bushaw (Lewis \& Clark Law School, Oregon), Ronald C. Cuming (Saskatoon), Sidney DeLong (Seattle), Hans-Eric Rasmussen-Bonne (Dresden Int'l University) and Jacob Ziegel (Toronto). I'd like to express my gratitude for the help also to Petar Kojdić (Schoenherr, Belgrade office), Péter Suták (MKB Bank, Hungary) and Karen Hammersmith (Collateral Certification Services, LLC). E-mail: tajtit@ceu.hu (Received: 08.04.2014; revision received: 24.06.2014; accepted: 24.06.2014) 
"Creditors incur the expense of field warehousing not for the purpose of creating or perfecting a security interest but in order to deprive they debtor of possession. [Moreover], [creditors] choose to deprive him of possession ... not because they fear he will use the inventory but because they fear he will sell it and that buyers in the ordinary course will [...] defeat the secured party."

[Emphasis added]. ${ }^{1}$

\begin{abstract}
"With the advent of Article 9's floating lien, it is no longer necessary to perfect by taking possession through the warehouse. Field warehouse companies now survive because their meticulous monitoring of the release of inventory serves a business purpose."
\end{abstract}

[Emphasis added. $]^{2}$

"The public filing will give notice to any third party smart enough to search, and taking possession will give notice to anyone who does an inventory of the debtor's assets. In theory, these public acts minimize the capacity of the debtor to borrow twice against the same collateral or otherwise to mislead subsequent potential creditors."

[Emphasis added]. ${ }^{3}$

\title{
INTRODUCTION: THE ROADMAP TO THE ARTICLE
}

This article is of an exploratory nature. It aims to take a closer look at field warehousing a constructive possession-based inventory financing security, financing and occasionally also distribution device - from a comparative perspective. Additionally, this topic lost its glamour even in the US, where it had presumably the most successful career ever, as it became "faceless" by being absorbed by UCC Article 9 largely in the 1950s and its subsequent economic decline. Similar reasons made out of field warehousing a step-child hardly focused upon by recent generalist secured transactions law reform projects. The financing potentials hidden in it (field warehouse receipt financing) were dealt with only by some agricultural finance projects and its potentials as an inventory-financing device have been neglected (Kohn 2001: at 42). ${ }^{4}$ At the same time, field warehousing industry has virtually boomed in the last decade or two in some Central and Eastern European (CEE) post-socialist countries like Hungary as well as in some emerging markets. ${ }^{5}$

1 Dolan, F. J. (Aug. 1978): The Uniform Commercial Code and the Concept of Possession in the Marketing and Financing of Goods, Texas Law Review, 56 (7): 1147, at 1164.

2 Winship P. (1998): Selected Security Interests in the United States. In: Norton J. and Andenas M. (eds), Emerging Financial Markets and Secured Transactions. Leiden: Kluwer Law International, at 273.

3 White J.-Summers R. (2010): Uniform Commercial Code. $6^{\text {th }}$ ed., St. Paul (US): West, $\S 23-4$, at 1194 .

4 The planned but eventually given up project on a possible Convention on Inventory Financing of the United Nations Commission on International Trade Law (UNCITRAL) contemplated to deal also with field warehousing though, which requires "the lender [to] exercise a substantial degree of control over the outflow of the inventory [and] which either may be impractical or may add a significant layer of cost to the lending arrangement."

${ }^{5}$ A good example is the case of the Pakistani 'Fauji Fertilizer Company,' which supplies fertilizers from 100 field warehouses spread all over Pakistan. See Company Profile in: Economic Review (1 Sept. 1998), paper downloadable from < http://www.thefreelibrary.com/_/print/PrintArticle. aspx?id=21266246 >; last visited on 29 July 2014. 
The complexity of the topic, the lack of empirical evidences and the scarcity of comparative scholarship dooms the ensuing elaboration partially incomplete, too. Further, this paper is limited to revisiting US field warehousing law and posing related questions from the perspective of two European laws: English ${ }^{6}$ and Hungarian law. This choice is, on one hand, admittedly driven by the languages spoken by the author and the availability of related materials in case of the latter country. On the other hand, it is of heightened importance that these countries represent also two extremes from Europe: while field warehousing is unknown in the UK, it has become one of the (if not the) most widely exploited security devices in the latter. As it will hopefully be seen, the juxtaposition of these three legal models (i.e. US, UK and Hungary) will cast new light on this constructive possession-based security device and would prove that the revisit of the topic is justified even in the US.

The roadmap to the article is as follows. First we will take a closer look at the cognitive and practical benefits this exercise is likely to generate together with a brief clarification of what field warehousing means to properly define our central object of observation. Secondly, once we enter the rich vineyards of comparative law, we will also realize that there is no commonly subscribed to nomenclature in the field, what requires special caveats to make the narrative and orientation possible. In the third part, US field warehousing law will be scrutinized as the benchmark chosen. Yet instead of simply retelling what Gilmore, Skilton, Kripke and other great names of US secured transactions had already written on the topic, the literature and cases will be taken a look rather from the positions of the other two targeted jurisdictions. Needless to say, the perspectives and thus also the key dilemmas tend to differ from the US ones.

Fourthly, a detour will be made to Hungary and the UK. This in case of the latter cannot be but limited to canvassing the theory on why this peculiar security device has failed to emerge in this country. The somewhat longer and the first English language account of Hungarian developments is due to the success and instructive history of field warehousing in this post-socialist Central European (CEE) jurisdiction. The scarcity of writings, as well as of systematized empirical evidences is due that in addition to conclusions we have no other option but to finish the elaboration also by formulating questions for further research.

Before moving to the next topic, a cautionary word on what is meant by 'field warehousing,' or rather what its key features are, is a must. Namely, what this designation exactly covers has changed over time even in the US, its cradle. While we can subscribe to Dolan's description that "[the] field warehouseman operates a manned physical enclosure located at the debtor's place of business and acts as the creditors' agent" (Dolan 1978: at 1164), the importance of other often presumed features is dubious. Pressed by historic cases, quite a number of US lawyers, for example, think that engagement of the debtor (its employee) in the running of the field warehouse is also a sine qua non. Similarly, from a US perspective it could validly be added, though with a much lesser persuasive force, that field warehouses characteristically issued non-negotiable rather than negotiable warehouse

${ }^{6}$ A caveat ought to be added here. Namely, field warehousing has remained unknown in the UK and the conventional explanation for that is likewise shared among the UK scholars. In other words, the English position here should be understood to extend also to the UK. When discrepancies exist like in the case of Scotland - that will be specifically noted. 
receipts (Gilmore 1965: at 152). ${ }^{7}$ These features are, however, characteristic primarily to the US and not necessarily shared by other jurisdictions having a statutory background. In brief, one should acknowledge the existence of national discrepancies yet they do not make the ensuing elaboration impossible as the core of field warehousing is shared.

\section{WHAT JUSTIFIES THE RENEWED FOCUS ON FIELD WAREHOUSING?}

\subsection{The First Reason: The Economic Potential Inherent to Field Warehousing and the Fluctuating Importance of the Industry}

The main rational for revisiting the esoteric security device of field warehousing known under this designation primarily in the United States (US) is of economic nature and relates to financing. It is a fact that the economic potential hidden in the modalities of this version of warehousing is substantial as demonstrated by examples not just from the US or Hungary but even from some emerging systems (Jacoby-Saulnier 1944). ${ }^{8}$ The US history with this security device going back to the $19^{\text {th }}$ century and the post-1990 developments of Hungary, as it will be shown hereinafter, readily proves that. For one thing, its growth was unbroken in Hungary in the post-1990 period. This claim is valid also vis-à-vis the US where its importance has fluctuated over time. Detailed quantitative data normally available for other types of secured transaction industries (e.g., leasing or factoring) is, however, hard to find not just in emerging markets but also in Europe or the US.

In the US, the advent of the Uniform Commercial Code (UCC) (Jacoby-Saulnier 1944: at 42) ${ }^{9}$ denoted also the decline but not a disappearance of field warehousing. If adjudged based on the available law review and industrial publications, its presence remained meaningful until the early 1980 s, though field warehousing companies figure on the yellow pages of business directories even today. Industry representatives tend to attribute that to two main reasons: the consolidation of the US banking sector and increased competition on the market (Lurie-Pope 2008: at 74-76). Most importantly, "large banking powerhouses" came to dominate the market. These banks are financially strong to operate their own departments for management of asset-based loans and directly police the

7 Gilmore in his treatise Security Interests in Personal Property in $\S$ 6.2., at 152 stated that "[t]he arehouse receipts are typically non-negotiable and name the bank as the person entitled to the goods." The author of this paper was not in the position to determine to whether, and if yes, to what extent has this changed in the meantime. At any event, UCC Article 9 still reckons with both, negotiable and non-negotiable receipts. See section 9-312(c) on negotiable documents and (d) on nonnegotiable documents.

8 See, for example, the already mentioned Pakistani 'Fauji Fertilizer Company,' which supplies fertilizers from 100 field warehouses spread all over Pakistan. See supra, note 6.

9 For example, in 1941 about 1,700 banks, or 13 percent of the then operating 13,500 insured banks, had extended field warehousing-based credits. Although this was less than the credits approved based on accounts receivable financing "which [was] estimated to be a regular practice of about 25 percent of all commercial banks," it was far from negligible. See Jacoby-Saulnier 1944. Although no such quantitative data are available related to the role of field warehousing for the $21^{\text {st }}$ century financing practices in the US, links to companies offering these services could be found. See, e.g. the webpage of the Collateral Certification Services LLC at ( $<\mathrm{http}: / /$ www.collateralcert.com $>)$; last visited on 29 July 2014. The predecessor of this company in 2009 used to be named as the Field Warehousing Corporation. 
collateral. The relatively long "covenant-light" (Wood 2008) ${ }^{10}$ period of stability and growth lasting essentially until the 2007 Credit Crunch allowed for the elimination of the extra-costs payable for the services of field warehouses (Lurie-Pope 2008: at 74).

Legal scholars from the US would rather explain the declined interest for and the subsequent metamorphosis of the industry with unfavorable court decisions. This applies primarily to the notorious 1976 Tanbro Fabrics (Dolan 1978: at 1151) ${ }^{11}$ case (the New York Rule). The court in the case was of the opinion that certain buyers could qualify as buyers in the ordinary course of business even though not taking possession of the goods bought. This ruling, as commentators put it, "[provided] every buyer with a key to the field warehouse lock” (Dolan 1978: at 1151). As predicted by Kripke (Kripke 1977: at 153; Gottlieb 1978), ${ }^{12}$ the Tanbro Rule had dealt a blow not just to the textile industry (Gottlieb 1978: at 2611) $)^{13}$ directly affected by the Rule but also to the field warehousing industry. It took a surprisingly long time to remove the obstacles caused to the industry as only the 1999 Revised Version of UCC Article 9 expressly rejected the Tanbro Rule (Frisch 2001: 813, at 835). ${ }^{14}$ It may be speculated that in the post-Credit Crunch era field warehousing gained heightened attraction once again in the US.

The intensity of the industry's presence, in other words, fluctuates with the changing economic conditions. Indirect evidences in the form of advertisements specifically offering 'field warehousing' services could relatively easily be found in the US (Gamble 2009). ${ }^{15}$

10 As it is known, the function of covenants in loan agreements is to "[confer] an entitlement to some voice, however, muted, [to the lender] in the management of the [debtor's] business [and affairs]." They may preserve the equal ranking of the lender's claim, preserve the assets, allow the lender control the debtor or influence the debtor's growth. See in general Wood 2008: section 8-01 et seq. As a rule of thumb, the number and severity of covenants increases in times of crisis and decreases in periods of stability and growth. The expression 'covenant-light' refers to loan agreements that do not contain a number of covenants usually relied on in risky-times.

11 Tanbro Fabrics Corp. v. Deering Milliken, Inc., 39 N.Y.2d 632, 350 N.E.2d 590, 385 N.Y.S.2d 260 (1976). The case did not concern field warehousing specifically but a resembling custom in the New York textile industry of the so-called "textile converters." These businesses purchased larger quantities of unfinished textile on credit to dye or process them ("to convert them"). If they could not sell the entire quantity, they resold the surplus to other converters. The key point is that in they relied on perfection by possession ("bill and hold practice"). For a detailed description of the facts of the case see Dolan 1978.

12 Professor Kripke cautioned then that the Tanbro Fabrics Rule "has dangerous possibilities for extension to field warehousing and other document of title situations; " a position not subscribed to in those days by many. See Kripke 1977. For a response to Kripke see Gottlieb 1978.

13 The decision "startled the textile industry, scrambled its traditional security devices and jeopardized the existence in this State (i.e. New York) of an important element of that industry, the independent converter."

14 See UCC s. 9-320(e) and point 8 of the Official Comments thereto stating that the section rejects "the holding of [Tanbro Fabrics - 1976] and, together with Section 9-317(b), prevents a buyer of goods collateral from taking free of a security interest if the collateral is in the possession of the secured party." American Law Institute \& the Uniform Law Commission (1999): Revised Article 9 (1999) Revisions - Official Comments. United States, ALI \& ULC (hereinafter: UCC Official Comments or Official Comments). See also Frisch 2001.

15 Very illustrative in that respect is how Microsoft has "dusted off some basic tools" - among others field warehousing - to 'hedge against risks, secure the credits and distribute' amidst of the new economic circumstances. As they put it "....another way is to operate a field warehouse within a customer's warehouse-sometimes literally marked off with yellow tape. While it's legally your 
One of the reasons that make the industry somewhat obscure is that it underwent substantial alterations in the meantime to fit the changed business expectations. It seems that field warehousing has become only a stage, or one of the components, of a more complex package of services increasingly known as 'collateral management' (Rogers et al. 1994: 149, at 158-159; Budd 1995; Dundas 2013: 89-97), ${ }^{16}$ 'collateral certification' ${ }^{17}$ or 'inventory control programs' (Lurie-Pope 2008: at 76). ${ }^{18}$ It may also be speculated that in some laws kin of field warehousing are known exactly under these, or resembling, labels. What seems to be common no matter which part of the globe is spoken of, due to the freshness of these developments and the fact that the glory days of field warehousing are obviously gone, legal scholarship lags substantially behind these developments. Even if doomed to disinterest in the US, the lessons that could be drawn by emerging markets based on them elevate this topic to the pedestal of top priorities. The reason is that in emerging markets - characterized also by a relatively low 'rule of law index' - the market and other systemic conditions existent in the US could hardly be replicated overnight. At any event, the US case amply demonstrates that field warehousing remains a valuable solution for high risk finance even in the most developed systems, be it only a panacea for some specific

warehouse and your merchandise, you can help your customers reduce their working capital and shorten the procure-to-pay cycle. But if the customer declares bankruptcy while the merchandise still sits on your side of the yellow line, you can take it back. Operating a field warehouse is cumbersome and expensive, though [...]."

${ }^{16}$ This old and new expression has two considerably differing meanings that may cause confusion. As far as our central topic is concerned, typically older sources talk of 'collateral management' as extending also to field warehousing. As an example, a panel discussion-based article from 1994 reads: "The collateral management industry began before Article 9 of the Uniform Commercial Code was adopted. [...]. Today the collateral management industry is primarily employed for the growing middle-market companies, whose creditors want to remain in touch with the assets on which they are relying".

See also Budd 1995: 120, at 121 claiming that "[w] ith the adoption of the UCC, and perhaps more importantly, the increased sophistication of local banks in collateral management and competitive pressures, field warehousing as a security device has all but disappeared except in large-scale banker's acceptance financing programmes [...]."

This meaning focused on secured transactions seems to have gradually been replaced by a novel one that places 'collateral management' to the field of capital markets and use of investment property as collateral especially used in over-the-counter (OTC) trade a world completely different from warehousing.

On the presence of 'collateral management' in Europe see, e.g. the decision of the Federal Supreme Court of Switzerland of 20 August 2012 related to the validity of the arbitration agreement in the underlying 'collateral management agreement' involving a Swiss and a Dutch firm, a Swiss bank (lender) and a fourth company entrusted with storing and handling of the collateral. Unfortunately, as the publicized portions of the decision focused on the validity of the arbitration clause, the details of the 'collateral management agreement' were not discussed. See Dundas 2013.

17 See, e.g. the website of the US Collateral Certification Services, LLC at $<$ http://www. collateralcert.com >; last visited on 29 July 2014.

18 It ought to be added that this publication was written by authors linked to the industry and that no publication seems to exist on the size and profile of the industry in the $21^{\text {st }}$ century. Thus, it is now known whether the role of field warehousing has increased as a consequence of the turbulences caused by the 2007 Credit Crunch and the subsequent financial crisis. 
high-risk niche markets, or a more generally applicable tool for years of depression or economic crises (Lurie-Pope 2008: at 76). ${ }^{19}$

The verdict on the economic importance, actual or potential, would not be complete without listing the advantages of field warehousing over its main rivals: on the one hand, terminal (public) warehousing and, on the other hand, the various non-possessory security devices (e.g., consignment, chattel mortgage, conditional sales or trust receipts). As far the latter category is concerned, even though they are now subsumed under the unitary concept of security interest in the US and other Unitary Systems ${ }^{20}$ and are therefore subject to a common set of rules (e.g., perfection by filing), their separate treatment is justified by the fact that most of them in reality continue to have a distinct life. Similarly to field warehousing, they are also "faceless" under the common category of 'secured transactions,' however, in economy often distinct industries live from only one of them. A good example are leasing or factoring (receivables financing) companies. This, however, is not characteristic to the two other targeted jurisdictions: while the UK refuses realignment with the Unitary Model, Hungary reformed its system yet transplanted only some of its building blocks. Finally, the clarification of the relation of field warehousing and escrow is required not just because of the resemblance of the two but also because of the spreading of the latter in civilian systems.

\subsubsection{Field versus Terminal (Public) Warehousing}

Field warehousing is to be distinguished primarily from terminal (public) warehousing though it grew out of it. Thus, they share a number of common features, starting from the fact that both can be perceived as professional industries providing services [also] to commercial banks (i.e., terminal warehouse receipt v. field warehouse receipt loans). While terminal warehousing could be pointed at as the paradigm warehousing form, its field variant is a derivative. The crucial difference between the two is that field warehousing is a bespoke transaction, more fitted to the needs of the parties than its senior counterpart in case of which much less choice is available. While in the case of terminal warehousing it is the borrower who transports the collateral to the warehouse, in case of the 'field" ${ }^{21}$ version it is the warehouse company that goes to the place where the debtor's inventory used as collateral is located, where it creates an artificial but sufficiently safe warehouse for the sole

19 The industry stressed in 2008 that even in no-crisis times in addition to reliance on mere monthly financial statements and monthly inventory and/or accounts receivable lists supplied by banks' debtors they can provide as well $1 /$ weekly reports with more exact data on "in-and-out activity and the inventory balance on hand," 2 / periodic inventories, 3/ "restrictions requiring a certain level of inventory to remain on hand at all times or required payments to the lender at specific release levels or times," 4/ specific tests for slowly moving or obsolete inventory, and 5/ constant inventory records displayed on the warehouse's website for checking but also for giving release instructions.

20 The 'Unitary Systems' or the 'Unitary Model' is a shorthand reference to the comprehensive secured transactions law materialized in UCC Article 9 resting on the 'unitary' concept of security interests. Besides Australia, the provinces of Canada, and New Zealand, Book IX of the European soft law instrument known as the 'Draft Common Frame of Reference' (DCFR) have embraced this model; naturally with modifications.

${ }^{21}$ In the US, the non-outposted warehousing is known as 'public' or 'terminal' warehousing. Typically warehouses begin with the terminal version first and only at a later stage expand to field warehousing. The present time Hungarian developments prove that. 
purpose of holding and safekeeping the inventory-collateral as a bailee (Garner 2001). ${ }^{22}$ In the US, the transaction was eventually recognized by courts as valid already somewhere by the end of the $19^{\text {th }}$ century and "the term 'field warehousing' or a variant [began] to appear in the case reports [already] during the 1900s" (Gilmore 1965: § 6.3, at 154).

The main advantages of field warehousing over its elder kin are the following. Firstly, often storage in public warehouses is not available (especially in peak harvest periods) or there is no reliable system of such enterprises in a given country. Frequently the borrower has adequate storage space that can then be exploited at a lower cost. Secondly, handling of some particular types of good may be additionally problematic; like bulky goods or goods the moving and transportation of which requires special equipment, insuring what adds extra costs. Thirdly, especially in processing industries the goods have to be close to the production's location when they are continuously needed, for what field warehousing is the optimal solution (Skilton 1961: 222-225).

Last but not least, the processes employed by field warehouses are more flexible and adaptable to the needs of the borrower (McGuire 1974: at 270). ${ }^{23}$ In fact, at least based on US historic experiences, in the pre-UCC period the widespread use of field warehousing was due to a great extent to the fact that it fitted a particular type of business: the "small or medium size manufacturing or wholesaling business unable to borrow all the money it needs on an unsecured based at a favorable rate [and the] large proportion of the total assets [of which] consists of inventory" (Skilton 1961: at 224). The services of the field warehousing company become even more sympathetic if the inventory "fluctuate[d] widely in the course of a year because acquisitions and sales are not closely correlated" (Skilton 1961: at 224). In other words, it has remained suitable for short term financing of inventory. As exploitation of the capital markets is still no more than wishful thinking (especially for small and mid-size companies) in most of the globe's economies, this fact just further corroborates the usefulness of security device being in the center of our observations.

\subsubsection{Field Warehousing versus Non-Possessory Security Devices}

The relationship of field warehousing and the various non-possessory security devices (in particular, chattel mortgage, consignment, factor's lien, trust receipt (Ellinger 2003: at 309; Duggan-Brown 2012: at 47) ${ }^{24}$ and floating lien (Ziegel-Geva-Cuming 1995; LoPucki-

22 Black's Law Dictionary defines it as follows: "[It] is a method of financing an inventory that cannot economically be delivered to the creditor or third party. The borrower segregates part of the inventory and places it under the nominal control of a lender or third party, so that the lender has a possessory interest." As per the description in the case Business Factors, Inc. v. Taylor-Edwards Warehouse \& Transfer Co., 585 P.2d 825, 828 (Wash. Ct. App. 1978), “[f]ield warehousing is a way of bringing about the security relationship of a pledge. It is an arrangement for allowing the pledgor a more convenient access to the pledged goods, while the goods are actually in the custody and control of a third person on the pledgor's premises." See Garner 2001 (hereinafter: Black's Law Dictionary).

${ }^{23}$ See McGuire J. T. (1974): The Impact of the UCC on Field Warehousing. Uniform Commercial Code Law Journal 6(1974): 267-283, at 270.

${ }^{24}$ Note that the concept of 'trust receipt' referred to in this paper is a security device primarily known in the US. Black's Law Dictionary defines it as a pre-UCC security device and "a method of financing commercial transactions by which title passes directly from the manufacturer or seller to a banker or lender, who as owner delivers the goods to the dealer on whose behalf the banker or lender is acting, and to whom title ultimately goes when the banker's or lender's primary right has been satisfied." For English law, it is a considerably different security device "the main object [of which] 
Abraham-Delahaye $2013^{25}$ ) that are not perfected by transfer of possession but by filing (registration) often unduly escape attention. This obscures communication as the recent secured transactions reforms have invariably focused on the latter only, devoting only minor attention (if any) to possessory (including its constructive variant) securities as if they had become completely ill-suited to modern times. Yet field warehousing is such a form of short-term security device that has not just survived but is in fact growing in some jurisdictions - like in Hungary. Moreover, for emerging markets and their vulnerable segments of the economy characterized by high risk (e.g. agriculture), or small and midscale businesses (SMEs) that can realistically offer as security only their products (i.e. inventory) or their receivables, exactly pledging of warehouse receipts issued by terminal or field warehouses may be the token of continued access to the much needed financing under tolerable terms and conditions.

The main conceptual difference between field warehousing and non-possessory security devices - including the floating charge or lien (Ziegel-Geva-Cuming 1995: at note 33 at 86; LoPucki-Abraham-Delahaye 2013: at 1858 $)^{26}$ - is that the former is per definition also a collateral-policing (or control) device. Unlike the non-possessory devices leaving

is to confer on the bank protection against the customer's insolvency without creating a registrable security." See Ellinger 2003.

It is interesting to note, that the US concept of trust receipt was added to the personal property security acts of Australia and Canada (except Ontario and Quebec) even though it had not been known in practice before the reform of these systems along the lines of UCC Article 9. See Duggan-Brown 2012.

25 A terminology caveat needs to be added related to floating securities. Namely, conceptually the English 'floating charge' is not equal to the US 'floating lien'. On the one hand, while the former is a separate nominated security device known since the $19^{\text {th }}$ century, the latter is rather a construct resting on more elements of UCC Article 9 (e.g. the abandonment of the Benedict rule, the concept of proceeds, filing). On the other hand, as the Canadian common law provinces were forced to realize because of being under the influence of both systems that "the English-style floating charge under the new legislation [i.e., the provincial Personal Property Security Acts taking over the UCC Article 9 unitary model] [was] converted into a fixed charge with an implied licence to the debtor to carry on business. [...]." See Ziegel-Geva-Cuming 1995. However, here we may use these two terms interchangeably as their conceptual differences do not affect their relationship to field warehousing.

For a somewhat contrary argument that disagrees with "portray[ing] [the two] as fundamentally different" and proposing that "the two function in essentially the same way" see LoPucki-AbrahamDelahaye 2013.

${ }^{26}$ For our discussion - being limited to the analysis of the question whether the floating charge or lien is a full scale functional substitute of field warehousing - the following ought to be noted. First, the floating charge is a device of English law (and its followers), is similar but hardly equal with the US floating lien. Their commonalities include that (at least theoretically) both can extend on all present and future assets of a debtor and that both leave unfettered dominion with the debtor. The key difference is that while the American device creates a priority position at the moment it is perfected by filing, its English kin does that only at a later point in time - at 'crystallization' of the charge. This basically means the time of default.

As the Canadian province of Ontario was first exposed to the dilemma what to do with the conflict of the inherited and in practice widely used English floating charge and the floating lien imported from the US when reforming the system along the lines of UCC Article 9 in the second part of the 1960s; Ontario was also forced to resolve the conflict first. The result was, as Ziegel put it, the floating charge was transformed into "a fixed interest with an implied licence to the debtor to continue to carry on business." 
unfettered dominion over the collateral in the hands of the debtor, here a third business physically controls what is happening to the collateral. What is a sine qua non of field warehousing is something that may but must not be additionally agreed upon, for example, with a collateral management company in case of non-possessory devices. As Skilton put it, in case of field warehousing the secured creditor "would depend not solely upon the integrity $^{27}$ of the borrower, but also upon the ability of the warehouseman issuing the receipts to establish and maintain effective control over the inventory" (Skilton 1961: at 224). In other words, field warehousing has a physical dimension in addition to being a legal construct. For example, while for the constitution of trust receipts US law requires no more than making of a contract and filing (i.e. simplified registration), field warehousing requires taking also of effective possession through undertaking of some physical acts, too. It manifests itself in the physical world by the segregation of the collateral, sign postings, the presence of the custodian (guards): i.e. real control by a third party professional, the warehouseman. This is why field warehousing is also a device for high risk finance (Friedman 1942: at 993). ${ }^{28}$ True, nothing prevents the parties to field warehousing agreements to allow for the bank's right to make unannounced visits to inspect the segregated warehouse and the books, yet that comes only as a supplement to the control and services of the field warehouse itself.

As a final point, albeit in the pre-UCC period field warehousing was used primarily as a self-standing device and as a substitute of non-possessory securities in high risk finance cases, their combination was not unknown either. Skilton suggested the taking of factor's lien as additional protection to the control of the warehouse because "factor's lien [could have been constituted] upon all of the debtor's present and future merchandise [including] goods in the field warehouse, good on the premises not as yet placed in the warehouse, and goods on the premises which have been released from the warehouse" (Skilton 1961: at 418). In another scenario described by Friedman, the warehouse receipts representing the field warehoused goods to be used in the production process were given by the bank to the manufacturer-borrower on a trust receipt to allow withdrawal of for the production necessary quantities of goods. The manufacturer, having the product, either returned it to the warehouse, or sold it and paid the loan off with the proceeds (Friedman 1942: at 992).

These examples from the pre-UCC period merit attention even in the US irrespective that UCC Article 9 has brought the different pre-UCC independent security devices under the same roof and in principle each of them (or the ones yet to be invented) could be substituted by a contract simply named as 'security agreement' and are subject to the same set of rules. Most importantly, the dilemma whether to rely on a non-possessory security device rather than on field warehousing, or whether to combine the two, remain valuable strategic considerations both, within and outside the US. This applies especially to emerging

27 As hinted at, the secured creditor has the choice to engage a professional collateral management company to maintain the integrity of the collateral by policing it. However, that is not a statutory prerequisite of the validity of non-possessory security interests. Needless to say, the 'debtor's integrity' mentioned by Skilton is dependent also on whether the debtor has additional credits and what kinds of covenants those credit agreements contain. Defaulting on any of the credit agreements may then, through cross-default clauses or otherwise, affect the entirety of the debtor's property - and its 'integrity.'

${ }^{28}$ Related to the US see Friedman 1942. Even though this paper is hardly of recent vintage, the claim that field warehousing is a high risk finance device seems to remain valid also in contemporary America and outside the US. 
systems in which banks, businessmen and their counsel are about to, or are in the process of, fully understanding these devices - in particular field warehousing, the typically neglected a-typical security device.

\subsubsection{Field Warehousing versus Escrow}

At least two resembling features of field warehousing and escrow ${ }^{29}$ require a brief comment here. First, in both cases a third party, the warehousing company or the escrow agent, may be engaged to hold, among others, ${ }^{30}$ property "for a given amount of time or until the occurrence of a condition, at which time the third party is to hand over the [...] property to the promisee" (Garner 2001). Secondly, escrow may be exploited as well as a security device resembling but differing from field warehousing. The key difference relates to the possession of the warehouseman and the escrow agent.

Given that UCC Article 9 does not define possession but rather it delegates the determination of "whether a particular person has possession" to the principles of agency law, only the Comments thereto illuminate what perfection method is suitable to escrow arrangements. It departs from the premise that "[i]n a typical escrow arrangement [...] the escrowee holds possession of collateral as agent for both the secured party and the debtor." 31 [Emphasis added]. Given that such two-party-serving possession is inappropriate as a perfection method for the purposes of UCC Article 9, to make things work, as the Comments suggest, "prudence might suggest that the secured party obtain the agent's acknowledgement in order to ensure perfection by possession." 32 Save this caveat, neither the Comments, ${ }^{33}$ nor leading authorities conclusively exclude (White-Summers 2010: at $1207)^{34}$ the possibility of perfection of a security interest by possession in case of escrows.

This gloss on the relation of field warehousing and escrow deserves attention as escrow - as new-generation bank products - is spreading not just in Hungary but in other European civil law systems as well. Escrows have become standard offerings of CEE banks exactly under the English designation roughly during the last two decades. In the region, escrow is perceived as a banking (financial) product versus field warehousing as a device linked almost exclusively to agriculture. Hence, the two resembling transactions have been so far divided by an invisible yet efficient firewall that subsists between the world of banking and agriculture.

${ }^{29}$ Also termed as 'escrow account,' 'impound account', 'reserve account.' See Black's Law Dictionary. In some European languages the English 'escrow' was taken over without translation. For example, the Hungarian language website listing the account types Hungarian 'MKB Bank' specifically lists "escrow számla" or escrow accounts. See at $<$ http://www.mkb.hu >; last visited on 29 July 2014.

30 The escrow agent may hold also documents or an account.

31 See Comment 3 to UCC section 9-313.

32 Ibid.

33 The cautious language of the Comment 3 to UCC section 9-313 states that "[...] under appropriate circumstances a court may determine that a third person in possession is so closely connected to or controlled by the debtor that the debtor has retained effective possession, even though the third person may have agreed to take possession on behalf of the secured party." [Emphasis added].

${ }^{34}$ White and Summers who conclude that " $[w]$ here an agent may represent both parties, such as an escrow agent, the question is difficult" and it is uneasy to determine whether the requirement that the 'creditor' have possession is satisfied. 


\subsection{The Second Reason: Field Warehousing's Success in Hungary and the Unresolved Dilemmas}

From the point of view especially of agricultural finance, undoubtedly one of the key post1990 developments in Hungary was the rediscovery of field warehousing (or a version of it), a security device that has the richest history in the United States (US) and which is now named as 'artificial warehousing' ("müvi raktározás") in Hungarian. Namely, after the fall of the Berlin Wall and the re-privatization of agriculture, a 1996 statute introduced field warehousing as part of a new, market economy-based regulation of the warehousing industry. ${ }^{35}$ The sector has thereafter virtually boomed. However, in addition to the positive news, Hungarians were forced to realize at the price of quite a number of major fiascos what Americans had long ago noted: viz., that this security device is supposedly a "valuable method for monitoring untrustworthy debtors" (Baird-Jackson 1983: at 206) and that the knowledge of policing debtors is far from being a simple business. It should thus not come as a surprise that one of America's biggest field warehousing-related scandals, the Great Salad Oil Caper erupting in 1963 (Rutberg 1994: at 28-35), ${ }^{36}$ seems to have been repeated in Hungary numerous times just with different actors and under varying circumstances.

During these twenty-some years, however, no scholarly publication, expert opinion or media report has even mentioned that US secured transactions law should be consulted to avert repeating known mistakes. Moreover, the 1996 law on warehousing did not have much in common with the EBRD-guided secured transactions reforms (Tajti 2002; Tajti 2013) ${ }^{37}$ promulgated by the 1996 amendment of the Hungarian Civil Code either. While the latter was inaugurated with quite a meaningful attention in legal circles, the evolution of warehousing - conceptually linked to agriculture and perceived as not having linkages to secured transactions law - proceeded on a distinct path. This notwithstanding that naturally the Civil Code (both the old from 1959 and the new from 2013) contains provisions on

35 See the $48^{\text {th }}$ (XLVIII) Act of year 1996 on Public Warehousing ("1996. évi XLVIII. törvény a közraktározásról”) [hereinafter: Warehousing Act 1996]. The act was subsequently significantly revamped in 2013 by the $66^{\text {th }}$ (LXVI) Act of year 2013 ("2013. évi LXVI. törvény a közraktározásról szóló 1996. évi XLVIII. törvény módositásáról”) [hereinafter: Warehousing Act 2013].

${ }^{36}$ For a succinct description of the case, see, for example, Rutberg 1994. The schemer, Anthony de Angelis was eventually sentenced to 10 years in prison for the swindle as the head of the Allied Crude Vegetable Oil Refining Corporation. He was in the position to get credit from banks only by exploiting the name and credibility of the American Express Company as the warehousing receipts were issued by the company's subsidiary, the American Express Field Warehousing Corporation. The scheme of de Angelis was not discovered for about five years (1957 to 1963) because he "had a sophisticated system designed to quickly switch oil into tanks that were to be inspected and secret compartments that showed the oil and hid the water". Ibid. at 36.

37 EBRD launched, indeed, one of its main law reform projects, the secured transactions law reform project shortly after its creation at its Budapest meeting in 2002. The problems with agricultural finance, in particular financing of the acquisition of capital equipment to be used in agriculture, was one of the key reasons for opting for the project. Hungary was, however, not the only country of the CEE region that was supported by the EBRD in introducing a common-law inspired secured transactions system. As a result, EBRD documents are among the richest sources on CEE secured transactions law. For an insight into the reform, including the $2^{\text {nd }}$ round of amendments in year 2000, see, e.g. Tajti 2002. The brand new Hungarian Civil Code has stepped into force on the $15^{\text {th }}$ of March 2014 introducing a substantially revised and enlarged, though not impeccable, third version of secured transactions law (see the section devoted to Hungary below). See Tajti 2013; available also at $<$ http:// www.SSRN.org > or Researchgate. 
possessory and constructive pledge.$^{38}$ As a result, while in Grant Gilmore's classic Security Interests on Personal Property field warehousing is devoted a separate chapter, hardly could one find in-depth analyses on Hungarian secured transactions law with references to field warehousing.

Needless to say, the corollary legal questions abound. Notwithstanding the relatively strong comparatist tradition in Hungary nobody seems to have realized that the long and winding history of the secured transactions law of the US is a handy inexhaustible source of inspirations. This applies even more forcefully to modern times because in the US field warehousing seems to have already made another great step ahead and has been absorbed as a phase of more complex techniques; an even less explored perspective of commercial law in Hungary.

In addition to filling the gap in the scholarship, adding Hungary to our observations should be primarily for the benefit of emerging markets and linked international reform projects. First and foremost, the legal and economic environment of Hungary more resembles those of emerging markets than any one of the leading economies (Bahaa Ali ElDean 2002). ${ }^{39}$ This is of key importance because a large portion of the 'presumed' economic and legal preconditions that had been shaped in the US for decades (some stretching over a century) hardly could be replicated overnight in economies where embeddedness of law in businesspeople and many other elements normally spoken of as building blocks of the rule of law are lacking or are significantly lower than in the benchmark jurisdictions.

Additionally, the example of Hungary readily shows as well that introduction of a version of the floating lien is not a substitute of field warehousing but the two should coexist especially in economies, or market niches, characterized by high risk finance. Even though the Hungarian organic developments do not necessarily corroborate the findings of the above-mentioned otherwise prestigious international projects, hopefully it will be seen that it makes sense to enrich the analysis with the experiences of such transitory countries as Hungary as well. Namely, international reform projects, in addition to being typically drafted by experts from the same pool of developed legal systems, were primarily (if not exclusively) based on the laws and experiences of the very same top-notch jurisdictions. Another common malady of these projects is that they are based only on the laws in the form known today and they tend not to find it important to take a look at key historic cases that were based on conditions more resembling those of present-time emerging markets. As a result, often conclusions hardly matching the needs of emerging markets are being drawn and promulgated. The ensuing saga of the resurrected field warehousing properly corroborates these claims as well.

\subsection{The Third Reason: Cognitive Benefits and Remedying Comparative Law's Incomplete Account on Field Warehousing}

The comparative analysis of field warehousing would yield three main cognitive benefits. Firstly, as comparative law has failed to properly address the myriad, academically

38 The new 2013 Civil Code, for example, in section 5:94 regulates the modalities of possessiontransfers and 5:95 the pledging of securities ("értékpapírok"). Note that contrary to US law, under Hungarian law (similarly to many continental European civil law systems), warehouse receipts qualify also as securities.

39 A very good example is the book of Bahaa Ali El-Dean 2002: Privatization and the Creation of a Market-Based Legal System - the Case of Egypt that pondering on the viability of secured transactions law reforms in Egypt relied on the EBRD Model Law but as implemented by Hungary. 
challenging field warehousing-related topics so far, numerous issues remain open. The lack of a common nomenclature and the scarcity of comparative writings are handy proofs of that. As a perfect example of the void, one pivotal aspect of secured transactions law - its industrial underpinnings - has been almost completely neglected. It was not taken account of the pivotal role various professional industries play in the life of secured transactions law and what should emerging recipient systems do to create them? Field warehousing seems to be one of the best examples corroborating this claim. Unexplored are also the economic effects a properly functioning field warehousing industry may generate. This makes the topic important not just for the economy of emerging markets but also for those economies of Europe in which the financing of agriculture or small and mid-scale enterprises (SMEs) remains an unresolved problem and yet know not, or recognize only limited versions of this device.

Secondly, common law scholars have failed to scrutinize the so-called English position on field warehousing according to which the failure of this device to emerge on British soil was explained by the single factor of benevolent attitude of English law to floating charge. Given the close ties lasting well into the $20^{\text {th }}$ century, the same line of reasoning applies mutatis mutandis to Australia, Canada and New Zealand; ${ }^{40}$ systems that had not known of field warehousing either. This has very concrete practical ramifications because of the following. With a level of simplification, third reform countries who model themselves after English law may unwittingly yet erroneously conclude that introduction of floating lien makes field warehousing superfluous. As it will be shown, however, both the Hungarian and US developments defy that. In fact, it may be legitimately asked whether this issue has properly been researched in the UK or rather some of the functions of field warehousing simply have not been supplemented by any mechanism.

Last but not least, this paper will also attempt to enrich the knowledge on field warehousing by juxtaposing Hungarian and US developments what should be of importance as sources are scarce in particular on developments in post-socialist and emerging markets. Though finding of legal analyses devoted to the CEE kin of field warehousing in local languages is next to impossible, too. This notwithstanding that field warehousing is in some variant known in Europe as suggested by the few lines in the comments to few sections in a recent instrument produced by an elite group of experts of private law from the Member States of the European Union called somewhat unusually as the Draft Common Frame of Reference (DCFR).

\subsection{The Fourth Reason: Remedying the Inefficiencies of Law Reforms and Teaching Emerging Systems How to Police the Collateral}

Two types of international projects could be linked to field warehousing: the comprehensive (generalist) secured transactions law reforms and the narrower ones specifically targeting warehousing. Perhaps the main deficiency shared by both is that they have as a rule remained isolated from one another what was due to such mundane reasons as the diverging

40 Unfortunately the author of this paper was not in the position to locate any law review article that would have devoted, at least, some lines to field warehousing in the said jurisdictions. Yet see the website of the US Collateral Certification Services, LLC company at $<$ http://www.collateralcert.com/ $>$ (last visited on 29 July 2014), which proudly advertises that it provides "[c]ollateral management services throughout the USA, Canada and Australia" and asks "Did you know that any commodity or storable inventory can be field warehoused?" 
policy choices, differing expertise and not infrequently also rivalry of the sponsoring institutions and the participating experts. Furthermore, the paradigm categories placed in the center of observations were not identical either: while the comprehensives focused on non-possessory securities, the projects on warehousing put terminal (public) warehousing in the center. As a result, it is their common denominator that they have marginalized field warehousing. Furthermore, policing - meaning, variations and its importance - as an important corollary of secured financing has as a rule been bypassed by both as well, something that could have been properly explained and illustrated exactly by devoting more attention to field warehousing.

\subsubsection{Comprehensive (Generalist) Secured Transactions Reforms}

By comprehensive (generalist) reforms we mean reform projects aimed at upgrading of the existent secured transactions laws without narrowing the focus to any specific aspect of this branch of law. These abound especially in the post-1990 period though even here three distinct tracks of spreading the Unitary Model, or key elements enshrined into UCC Article 9, ought to be differentiated: first, the autochthonous receipt of the model by Australia

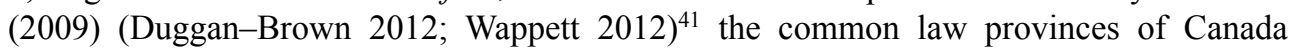
(Ziegel 2010: at 328 et seq) ${ }^{42}$ and by New Zealand (1999) (Brown 2010: at 117 et seq.), ${ }^{43}$ second, the international projects aimed either at assisting emerging markets to reform their laws $^{44}$ or at drafting documents not targeting any niche of the Globe specifically, ${ }^{45}$ and third, products of organic growth aimed at improving the inherited laws like that was the case recently in France or as it is the case with the soft law instrument named as the Draft Common Frame of Reference (DCFR). While the projects of the second category had modest economic output, the DCFR was put aside by the European Union (EU) and its future is highly uncertain. So much so that some, initially enthusiast western experts, have turned to skeptics of the viability of diffusion of secured transactions laws.

Apart from the obviously mistaken presumption according to which much of US or Canadian $^{46}$ secured transactions law could be replicated not just on paper but in reality -

41 The Unitary Model was introduced in Australia by the Personal Property Securities Act 2009 (Cth); the act came into force on 30 January 2012. The two leading authorities on the reform are Duggan \& Brown (2012), and Wappett. (2012).

42 The Canadian provinces adopted the model from 1967 onwards. The first province was Ontario enacting its personal property security legislation in that year and introducing the first computerized central registry until 1976 when the act became fully operational.

43 See the New Zealand Personal Property Securities Act 1999. For the idiosyncratic solutions of the New Zealand act from 'securities' (i.e. plural) instead of the singular used by the Canadian provinces that had served as the models see Brown 2010.

${ }^{44}$ Mention should be made primarily of the EBRD Secured Transactions Model Law and the other documents produced as part of the underlying project. The work of the Washington D.C.-based Center for Economic Analysis of Law (CEAL - < http://www.ceal.org $>$ ) should also be mentioned; in particular the documents related to Latin-America, some CEE countries and recently Nigeria.

45 Especially UNCITRAL and UNIDROIT ought to be mentioned, the former with its secured transactions project culminating in the UNCITRAL LEGISLATIVE GUIDE ON SECURED TRANSACTIONS (2010) and the latter with its Convention on Security Interests in Mobile Equipment (Cape Town, 2001). The documents produced by these two international organizations could be found on their websites.

46 While in the US this branch of law is known as 'secured transactions law,' in Australia, Canada and New Zealand - or for that matter even in the unreformed England - the proper designation is 'personal property security law.' 
moreover in the matter of a decade or less - in other parts of the world as well, each of the projects had a number of further weak points. One of those, and that is what matters for our purposes, was that none of them seems to have devoted special attention to field warehousing as a specific security device (or warehousing as a financing method). This is more or less logical given that each of such projects is also a learning process and readymade answers tested in a different legal and economic environment were lacking. Normally, only (if at all) symbolic mention is made of it as a form of constructive possession. ${ }^{47}$ As a result, it is fair to say, detecting and understanding how field warehousing operates behind the often extremely voluminous, convoluted and complex documents of secured transactions projects in the lack of prescriptive language, especially by lawyers or businessmen from countries without any experiences, nears impossibility. This is not an exaggeration given the economic importance of field warehousing especially in agriculture-dependent developing countries already hinted at.

\subsubsection{Sector-Specific Projects}

Besides the generalist secured transactions-related project, some targeting warehousing typically generally, mentioning but not explaining (if at all) field warehousing, have also appeared lately. These include documents of the World Bank (Höllinger-Rutten-Kiriakov 2009). ${ }^{48}$ United Nations ${ }^{49}$ or publications that have seen the daylight following the UNIDROIT Colloquium on 'Promoting Investment in Agriculture: Private Law Aspects (2011). ${ }^{50}$ It ought to be noted that if looked upon at field warehousing with eyes of lawyers from emerging markets, what is in particular lacking from these documents is information not just on the myriad risks that may give a death kiss to all fresh attempts of exploiting it but as well the variations whereby the business and financing expectations could be satisfied. This knowledge remains hidden exactly in sources the unearthing of which is attempted herein. Besides the precious experiences of Hungary, in particular, the long string of US historic court cases, the works of Grant Gilmore and other venerable names of US secured transactions scholarship not taken a look at anymore or in the story on why has field warehousing survived UCC Article 9; to wit, the importance and meaning of policing and understanding why is field warehousing a 'control device.'

47 E.g., the more than five-hundred pages long UNCITRAL (United Nations Commission on International Trade Law) Legislative Guide makes explicit mention of field warehousing only in two points on possession by a third party. See UNCITRAL (2010): Legislative Guide on Secured Transactions. New York, UNCITRAL, points 59-60, at 117. For the few sentences in the DCFR see the section on terminology below, note 74 .

48 Finding one's way among the many documents produced by the World Bank is a challenge and hence one can never be sure whether the list jotted down is exhaustive. Still, the document to be mentioned is the working paper by Höllinger-Rutten-Kiriakov (2009) presented at the World Grain Forum 2009 in St. Petersburg, Russia. [hereinafter: WB Working Paper 2009].

49 See, e.g., United Nations Conference on Trade and Development (Sept. 2009): Review of Warehouse Receipt System and Inventory Credit Initiatives in Eastern \& Southern Africa. Published by UNCTAD, available electronically at < http://www.unctad.info/upload/SUC/LusakaWorkshop/ WarehouseReceiptsSytemsReport11.05.pdf >; last visited on 29 July 2014.

50 The papers were published in the International Institute for the Unification of Private Law's (UNIDROIT) Uniform Law Review, XVII (1/2); a thematic issue devoted to promotion of investment in the agricultural sector. 


\subsubsection{Micro-Level Benefits: Improved Policing of Collateral}

On the micro economic level, the reform projects have remained extremely weak with respect to two overlapping and interlinked yet important issues: dissemination of the new laws as well as the failure to devise methods whereby the sine qua non industrial practices could also be transferred. Both were the product of the focus, even if unwittingly, on written laws. As a rule, the projects were reported as completed and successful once the target jurisdictions' parliaments have passed the new, typically common law-inspired secured transactions, or laws regulating the warehousing sector and hardly has anybody cared for the subsequent implementation. No tested method of dissemination seems to have surfaced so far. The attempts to draw some quantitative data based conclusions from the number of filings in the new charge registers seems to have reached the farthest. Yet field warehousing as a possessory security device is normally not subject to any kind of registration and thus could not be taken into account either in such reviews.

Industrial practices are of importance because they are the token of the success of reform projects. For example, transplantation of UCC Article 9 to the common law provinces of Canada, for example, could become a major success not just because of the resembling laws: the most important reason was rather the existence of mature professional industries which were capable of understanding and applying the novelties. These industries, however, are normally non-existent in emerging systems. No project seems to have, however, specifically dealt with this aspect of secured transactions laws.

The Hungarian developments readily corroborate the validity of this train of thought. Namely, in Hungary, the brand new Civil Code of 2013 brought with it also the third major revamping of secured transactions laws exactly to improve the discouraging records and falling number of filings. Yet as field warehousing has never been linked to the distinct path of secured transactions reforms, nobody has reckoned with the growth of the field warehousing industry; simply the two were not looked upon as something having anything in common. International projects as a rule suffer from the same deficiency. The lesson for future reforms is that building of an appropriate legal and institutional framework that would give the necessary leg-on to field warehousing deserves special focus and perhaps could produce more promising results in the short run than introduction only of nonpossessory securities.

Another negative repercussion of this cultural and communicational mismatch was that little, if any, attention was devoted to the role industrial practices play in the life of secured transactions. No better example could be given of direct relevance also to field warehousing than the neglected role policing of the collateral plays. In the US, one of the preconditions for the validation of the floating lien was exactly the abandonment of the Benedict rule and consequently nothing in the text of the UCC Article 9 even mentions policing. As professional industries know how important policing is and how to do policing, the system could rely on the expertise and wisdom of the participants to secured transactions: something that is simply non-existent in emerging systems. The ensuing discussion on field warehousing which is not only a security but also a control device is a way to shed light exactly on these hidden aspects of secured transactions law. Put simply, the narrative of field warehousing is also a story on policing hopefully leading to the realization that this security device is one of the best methods for high risk finance emerging systems. 


\section{PRELIMINARY DETERMINANTS EXPLAINED}

\subsection{Why is Terminology a Special Problem in this Domain?}

The context of field warehousing is a superb example of the obstacles unsettled terminology and translation standards may create. To a great extent this is attributable to the extreme complexity of secured transactions law itself. It is even more disorienting that field warehousing as a distinct security device, or the linked industry, are essentially invisible from the texts of secured transactions laws. Be it UCC Article 9, its most far reaching European kin - Book IX of the DCFR or the Hungarian Civil Code, search for 'field warehousing' would hardly lead to any results. In Europe, the result of this is that field warehousing is of interest to experts of agricultural finance rather than to experts of mainstream secured transactions law.

Another serious obstacle is that England, another common law jurisdictions leader in the realms of financial law knew of the fixed \& floating charge tandem but not of field warehousing. Consequently, English lawyers were not driven to coin specific terminology either for the latter. Put simply, field warehousing is as a rule lacking from the vocabulary of English lawyers. English text and case books typically devote only a very brief passage (if any) to it when mentioning US law. As even the leading experts of those common law jurisdictions that know not of the security device of field warehousing use US terms (McKendrick E. (ed.) 2010: 784): ${ }^{51}$ it makes sense therefore to depart from the established US nomenclature centered around 'field' versus public or terminal warehousing (Gilmore 1965: $\S 6.2$, at 148). ${ }^{52}$

The story does not end here, however. As hinted at already above, the industry underwent meaningful changes even in the US, where sometimes field warehousing became part of (i.e. one element of) a complex set of services increasingly referred to by varying novel designations from collateral management to collateral certification. Such novel designations and hence field warehousing as integral part of a more complex set of specialized services represent uncharted phenomena notwithstanding that their variants are gradually yet unnoticed appearing even in civilian systems. For example, while field warehousing as such seems to be unknown in Serbia, collateral management has been offered by the local subsidiary of a Dutch firm roughly since $2001 .^{53}$

51 Roy Goode, in his famous book Commercial Law - essentially devoted to English law - uses the field warehousing language in the section devoted to stocking finance (what in the US would be rather 'inventory finance').

52 Gilmore, the father of UCC Article 9, used 'public or terminal' versus 'field' warehousing in his Security Interests in Personal Property (1965).

53 The Serbian subsidiary is named "SGS Beograd d.o.o." The financial reports filed with the Serbian Company Registry for year 2012 reveal that the company is not dormant < http://fi.apr.gov.rs/ prijemfi/cir/Podaci_Komplet_1.asp?strSearch=17324594\&kod=d8754ae8f6b3d7ae120df8d26e07033 85 e3c0044\&godina $=2012 \& p k \_z a g=417545$ >; last visited on 29 July 2014. The English language bulleting of this company, as one of the services offered, mentions that "[...] [t]he commodities will be held either in a SGS warehouse, in an independent warehouse contracted by SGS, or in the plant or warehouse owned by the producer and leased to SGS." [Emphasis added]. SGS Bulletin downloadable at $<$ http://www.sgs.com/ /media/Global/Documents/Brochures/SGS-Agriculture-Col_ Management_Brochure_Update-EN-10-LR.pdf >; last visited on 29 July 2014. However, these services have not become routinely resorted to by banks in Serbia yet. 


\subsection{European Terminology Variants Stymieing Comprehension}

In Europe, thus, where none of the common laws knows field warehousing, communication perusing the new lingua franca - English language - is a real hurdle already because of that. If one takes a step towards civil laws, comprehension becomes even a bigger issue as some systems likewise are devoid of this security device; or so it seems. Making the next logical step and inquiring about the existence of this specific device by simply translating the epithet 'field' to any of the Continental European language would therefore be of no avail as other languages might use a different attribute.

The Hungarian kin device was statutorily named as 'artificial warehousing' ("müvi raktározás") ${ }^{54}$ which stresses another feature of the device yet is equally telling of its nature; though the 'rented' ("bérelt") warehouse is also traceable. This is, however, not the end of variations of designations. For example, in Croatia, where even though no indicia speak of the widespread use of field warehousing, the designations of 'separated' ("izdvojeno") or 'private' ("privatno”) warehouses are known as well..$^{55}$

In Germany, only one bankruptcy law commentary seems to mention field warehousing, describing only rather than coining a specific designation for it: viz., 'warehousing of pledged goods' ("Lagerung von sicherungsübereigneten Gegenständen") (LwowskiTetzlaff 2008: $\S 166$ InsO Rn 23f.). The comments mention field warehousing as a possible tool for avoidance of certain taxes payable and as a theoretical rather than a real option for preventing the bankruptcy administrator getting hold of the collateral. Albeit allegedly the idea was discussed among bankers, the commentary cautions against resort to field warehousing as an innovation that might be re-characterized by courts to security transfer; one of the most commonly used German non-possessory security devices on movables (Lwowski-Tetzlaff 2008: $\S 166$ InsO Rn 23f.). Otherwise, the English pages of some German businesses do use the phrase 'field warehousing' but with a meaning different from the one known in the US. The spectrum is otherwise prohibitively wide. One source erroneously equates field warehousing with the idiosyncratic German device of 'security transfer' ("Sicherungsübereignung") 56 which contrary to field warehousing is a non-

54 The law governing the field, the $48^{\text {th }}$ (XLVIII) of year 1996 on Public Warehousing ("1996. évi XLVIII. törvény a közraktározásról”) adds a further twist even on the level of Hungarian legal terminology because in its title speaks of 'public warehousing' ("közraktározás") which extends to its main two forms as defined in $§ 1(4)$ of the Act to 'own' ("saját tárolás") versus 'artificial' ("müvi tárolás") warehouses. The first of these hardly could additionally be even translated to English without adding some qualifications.

It should not come as a surprise then that one of the big Hungarian warehousing companies, the Korona Closed Joint-Stock Company ("Korona Közraktár Zrt."), in its Business Terms and Conditions ("Üzletszabályzat") starting with a list of definitions, found it important to use more precise designations. Thus, instead of the imprecise 'own warehousing' they use the phrase 'warehousing in the company's own premises' ("saját telepi közraktározás") and define 'artificial warehousing' as "all other types of warehousing but warehousing in the company's own premises." Hungarian text available at < http://www.koronakozraktar.hu/docs/uzletszabalyzat101207.pdf >; last visited on 29 July 2014.

55 See < http://www.eudict.com >; last visited on 29 July 2014.

56 Compare the English and German versions of $\S 9(4)$ of the Terms of Supply of the German company Cutmetall Komponenten $\mathrm{GmbH}$ at $<\mathrm{http}: / /$ www.cutmetall.de/en/unternehmen/agballgemeine-lieferbedingungen.html >; last visited on 14 March 2014. For the Swiss Easy Fairs company see < http://www.easyfairs.com/easyfairs-product-directory_36971/epd/view/Product/0/ warehousing/ >; last visited on the 29 July 2014. 
possessory security and additionally not being subject to any kind of registration. Another source talks of 'pledging-cum-security transfer on third person' ("Verpfändung und Sicherungsübereignung an Dritte"), ${ }^{57}$ suggesting the unease and confusion our object of observation generates.

Exactly because of these reasons, it is surprising yet relieving to see explicit references to field warehousing in the comments to the Draft Common Frame of Reference (DCFR) (Bar-Clive (eds.) 2010), ${ }^{58}$ a code-like soft law instrument drafted by EU scholars. Unfortunately, the few lines only suggest that field warehousing is known somewhere in Europe yet do not specify exactly where. Book IX of DCFR, even if not admitted in the comments, clearly was inspired by UCC Article 9 and most of its building blocks closely resemble, hence, it is not excluded that the existence of field warehousing was mechanically presumed yet without much (or any) empirical evidences gathered from Europe. In the text of the provisions of DCFR naturally there is no mention of field warehousing, just as is the case with UCC Article 9 itself or the new Hungarian Civil Code, yet it does extend naturally to forms of constructive pledge.

Apart from the mentioned few examples, the author of this article was not in the position to find the traces of field warehousing in Europe so far; to a great extent because of terminology conundrums. Likewise, field warehousing as a potentially useful security device in agricultural finance is not something figuring on the books of EU bodies. ${ }^{59}$

\subsection{Why Choosing the United States as the Benchmark Jurisdiction}

More reasons justify choosing the US as the benchmark jurisdiction for this paper. Most importantly, this specific security device "has never taken root" (McKendrick E. (ed.) (2010: at 784) in England; in the world of finance the other leading legal system. Yet in other major legal systems, it has had a much less spectacular development as a consequence of what the list of reported cases (if any) as well as the related scholarly output is much poorer and less instructive. Consequently, it should thus not come as a surprise that virtually nothing could be found on this topic in the works of UK or the scholars of major civil law systems (in particular in English language). It comes thus next to natural to opt for the rich vineyards of US field warehousing law as the benchmark.

The comparatively longest, almost two centuries lasting history of field warehousing in the US is helpful for other reasons as well. For one thing, it displays adequately how the economic role of this financing device has changed over time, depending on the exigencies of any one given time. For example, Friedman rightly highlighted amidst of the WW II that "the system of field warehousing is not new, but it has come into prominence only recently"

57 See the internet-based dictionary Linguee at $<$ http://www.linguee.de/deutsch-englisch/search ?source=englisch\&query=field+warehousing >; last visited on 29 July 2014.

58 Comment B to Article IX.-3:102 on Methods of achieving effectiveness, illustrating the modern time use of possessory pledges (i.e. perfecting by transfer of possession) reads: "Although [possessory pledge is] largely outmoded today, there are still situations in which this form of security can be useful, and not only for luxury goods or pieces of art. For economically relevant situations, recourse is often taken to so-called field warehousing." See von Bar-Clive (eds.) 2010: vol. six, at 5479. Paragraph C(c) of the Comments to Article IX.-3:201 on possession by creditor (as a form of perfection) mentions field warehousing as a form of constructive pledge. $I d$. at 5489 .

59 The author of this paper has specifically contacted the European Commission's DirectorateGeneral for Agriculture and Rural Development and has received the reply that no materials exist with the Directorate on field warehousing. Reply archived with the author. 
(Friedman 1942: at 991), and suggested that field warehousing was one of extremely useful financing devices in times of war economy.

Thereafter the enactment of UCC Article 9 by the States did not give a kiss of death to the field warehousing industry: businesses specialized to field warehousing have continued their activities yet in altered forms (e.g. collateral certification). Its importance has significantly fallen but they have not become extinct. Field warehousing became rather neglected and "invisible," a device thriving based on the few pledge-related - more precisely constructive or pledge by bailment - provisions in UCC Article 9. Part of the blame ought to be ascribed also to the new neutral terminology of the Article. ${ }^{60}$ This justifies dividing the history of US field warehousing law to two stages taking the appearance of the UCC as the watershed: the pre-UCC era characterized by growth and the post-UCC phase featured by decline. While in the first, field warehousing had its own separate existence, was a nominated transaction practiced by a distinct industry, in the latter it has been merged into the new secured transactions law.

For this reason, for the exploration of the changing nature of the device and its dependency on changed economic conditions obviously US law is more suitable than our other target jurisdiction, Hungary.

\section{THE THREE PILLARS OF FIELD WAREHOUSING LAW IN THE UNITED STATES}

No matter which phase of the evolution of US field warehousing law is observed, three inseparable yet distinguishable aspects of field warehousing law should be distinguished: to wit, the security aspects (i.e. field warehousing as an independent security device), the law on the warehouse receipts as documents of title and the prudential (e.g. licensing and bonding) regulation of warehouses. Each of these avenues has its own yet with the others overlapping history. It is crucial to realize that for a complete picture and for forging of a proper legal framework in emerging systems scrutiny and tackling of all three is a must.

While the security aspects of field warehousing are enshrined in UCC Article 9, UCC Article 7 contains rules on warehouse receipts (in fact representing the consolidated version of the 1906 Uniform Warehouse Receipts Act). ${ }^{61}$ The prudential (licensing) segment includes especially the federal Grain Standards and Warehouse Improvements Act (2000)

${ }^{60}$ Albeit all references to UCC Article 9 herein will be made to its 1999 Revised Version, based on the mandate in point 1 of the Comments to s. 9-101 of the Revised Version whereby "the Comments to former Article 9 [...] remain of substantial historical value and interest [for] understanding the background and general conceptual approach of this Article" references to the earlier versions of the Comments are inevitable. This is the case here as well. Section 1 of the Comments to the pre-Revised Version s. 9-105 aptly express the reasons behind the neutral terminology according to which "[...] a set of terms has been chosen which have no common law or statutory roots tying them to a particular [security device] form [to avoid] the implication that the [earlier] law referable to that [security device] form was to be used for the construction and interpretation of this Article".

${ }^{61}$ As the Official Comment to UCC $§ 7-101$ puts it: "[Article 7] is a consolidation and revision of the Uniform Warehouse Receipts Act [1906] and the Uniform Bills of Lading Act, and embraces also the provisions of the Uniform Sales Act relating to negotiation of documents of title." 
being limited to agricultural finance ${ }^{62}$ and its State kin (if any) sometimes applicable to other fields of economy, too. Albeit the two-level acts are supposedly in harmony yet tensions do exist related to warehouse receipts touched upon by both levels of warehouse laws (Kershen 1994: at 772). ${ }^{63}$ Needless to say, licensing, bonding and disciplining the industry as well as the regulation of warehouse receipts is normal in other developed systems as well and are a sine qua non also in emerging markets.

Albeit this paper focuses primarily on the security aspects of field warehousing, each of these ought to be taken a brief look at.

\subsection{Field Warehousing as a Specific Secured Transaction Form}

As the doyen of US secured transactions law, Grant Gilmore canvassed, field warehousing was one of the so-called independent security devices in the pre-UCC period of American history of secured transactions law that "was like a pledge, or a sort of pledge [and] a remarkably successful security device that managed to exist for nearly half a century before anyone realized that it was there" (Gilmore 1965: 146). Notwithstanding the fluidity of the concept, the drafters of the UCC have failed to include the definition of field warehousing. This has not changed in the meantime and hence precedents and the works of scholars remain to a great extent authoritative. Exactly which features of field warehousing are sine qua non thus has remained to certain extent open.

It should not come a surprise that cases emphasize different features of field warehousing but its 'pledge-nature', the custody and possession given to a third party warehouseman is not questioned. ${ }^{64}$ Due to this feature was field warehousing legitimized as one form of perfection of security interests; one of the two main functions it played in the

62 The Act's first version was enacted in 1916 and then amended in 1931 to make prudential regulation of warehousing in the area of agriculture federal exclusivity. See, e.g., points 14 of the holding in Rice v. Santa Fe Elevator Corp., 331 U.S. 218 (1947). The act was amended in 1990 and 1992 mandating the Secretary of Agriculture to introduce a filing system for electronic cotton warehouse receipts. The act was fully consolidated by the Grain Standards and Warehouse Improvements Act of 2000. Title two of the 2000 Act - shorthand reference: the US Warehouse Act regulated licensing. Text available at $<$ http://www.fsa.usda.gov/Internet/FSA_File/pl_106-472_ warehouseimproveact.pdf $>$. For an overview of warehouses licensed and examined by the Secretary of Agriculture see < http://www.fsa.usda.gov/Internet/FSA_File/whselst2010.pdf >. Both websites last visited on 29 July 2014.

${ }^{63}$ Kershen, who identified seven comparable sections in the said acts (e.g., the contents and form of warehouse receipts, illegally issued receipts, warehouse liens) yet concluded that although "[...] areas of tension between the [United States Warehouse] Act and Article 7 may exist that could lead to incompatible interpretations and results [yet] the Act and Article 7 are fully compatible."

${ }^{64}$ See Business Factors, Inc. v. Taylor-Edwards Warehouse \& Transfer Co., 585 P.2d 825, 828 (Wash. Ct. App. 1978), which characterizes field warehousing as "a way of bringing about the security relationship of a pledge [and] an arrangement for allowing the pledgor a more convenient access to the pledged goods, while the goods are [remain] in the custody and control of a third person on the pledgor's premises." A somewhat differently focused definition is given in In re Covington Grain Co., 638 F.2d 1362, 1365 ( $5^{\text {th }}$ Cir. 1981): "Field warehousing is ... an arrangement whereby a wholesaler, manufacturer, or merchant finances his business through the pledge of goods remaining on his premises. The arrangement is valid and effective where there is an actual delivery to the warehouseman by the bailor who has hired the warehouseman and given him exclusive possession of the warehouse goods." Both quotations were taken from the Black's Law Dictionary ( $7^{\text {th }}$ DeLuxe edition, 1999). 
context of secured transactions law. Contrary to consensus on its constructive pledge, its capability of serving as a security interest perfection form was questioned.

Furthermore, unlike Hungary and most emerging markets in which versions of field warehousing emerged linked to agriculture, in the US, the asset-type used as collateral was not so determinative (Gilmore 1965: $\S 6.3$, at 161). ${ }^{65}$ Consequently, while in emerging markets financing via warehouses is perceived to belong to agricultural finance, in the US it is rather an inventory-financing device. Last but not least, the indeterminacy inherent to the definition of field warehousing was counter-balanced by being "more routinized than any other financing arrangement, with the possible exception of the international letter of credit" (Gilmore 1965: $§ 6.2$, at 147). ${ }^{66}$ This professionalism and routinization has been of key importance because of the main function of field warehousing: viz., policing of the collateral by a third neutral professional. While the utility of field warehouses as legitimate perfection forms has virtually vanished with the UCC, the need for policing of the collateral has only subsided in the US. This is hardly the case in emerging markets where field warehousing is needed for both of the functions. These quintessential attributes must be considered in turn.

\subsubsection{Field Warehousing as a Form of Constructive Pledge (or Pledge by Bailment) and a Perfection Method}

Summers referred to field warehousing, not without a reason, as 'the progeny of pledge' (Summers 1963: at 150). The kinship, however, does not mean full overlap. Civil lawyers would perceive it as a device based on constructive possession for the collateral is, indeed, not transferred into the hands of the creditor but "only" of a third person to divest the debtor of his unfettered dominion (control). Common law would speak of that as "pledge by bailment.' Through such transfer of possession of the collateral, field warehousing is also a method of perfection of the security interest, even if not necessarily a perfect one as proven by a number of US cases. The lesson to be drawn based on this imperfection, highlighted also by leading US scholars (Baird-Jackson 1983: at 205-206), ${ }^{67}$ is that filing in addition to transfer of possession is advisable to ensure proper perfection of the security interest.

In economic terms, it has to be also added, there is an important difference in the utility of possessory pledges and field warehousing. Namely, while in case of possessory pledge possession of the collateral is taken out of the hands of the debtor whereby he is prevented from exploiting it to generate income to repay the credit, in case of field warehousing the retail merchant can continue his business only that the neutral warehouseman would release the goods to customers subject to the terms and conditions agreed upon. This feature of the latter makes it functionally quite closely resembling some non-possessory securities, like consignment.

65 As Gilmore noted, even though the canner is typically mentioned as "the prototypical client of the field warehouseman", the early (i.e. $19^{\text {th }}$ century) cases involved rather iron, steel, wool, paper, seeds, leather and lumber. The first reported case with canners was only from 1910 and was struck down as improperly run.

${ }^{66}$ In the US, issuance of international letters of credit was the "near monopoly of a few large banks in the half-dozen major financing centers." Ibid.

${ }^{67}$ As Baird and Jackson put it "although [field warehousing] is a valuable method of monitoring untrustworthy debtors, [it] creates substantial ostensible ownership problems [because] [signs] may not be seen, or, if seen, may not be understood [and] third parties cannot distinguish [the warehoused goods] from inventory held on consignment or held subject to a nonpossessory security interest." 
As the US experiences show, the difference is crucial and field warehousing should not be accepted as "an adequate surrogate for possession." 68 Consequently, not all field warehousing arrangements could serve as proper perfection methods either. Substantial case law emerged in the pre-UCC period exactly on the issue under what conditions may the various field warehousing arrangements be accepted as equal to possessory pledge especially for perfection purposes. The courts' benevolence largely depended on three criteria: 1/ the warehousemen-bailee's 'open, exclusive, and unequivocal possession,' $2 /$ the independence of the warehouse, and $3 /$ the status of the warehousemen. ${ }^{69}$ Ideally, exclusive possession was achieved by "locking the inventory within the leased area, set off by barriers such as the classic chicken-wire fence [and ...] exclusion of the borrower from access to the goods without authorization by the bailee." 70 In reality, courts were quite tolerant (Baird-Jackson 1983: note 89 at 206), ${ }^{71}$ which was to a great extent due to the heavy concentration and high professionalism of the industry making bankruptcy trustees and creditor counsel reluctant challenging field warehousing arrangements (Baird-Jackson 1983: at 675). The right qualification is that the decisions were fact-specific though "in the absence of some flagrant violation of the warehouseman's possession" (Baird-Jackson 1983: at 673) the field warehousing arrangements were recognized by courts.

The inherent indeterminacy of field warehousing "possession" and "perfection by possession" could not be resolved once and for all by UCC Article 9 either. Consequently, the pertaining rules have undergone meaningful changes over time hardly in the direction of simplification. Thus, while Monroe R. Lazere in his 1968 treatise Commercial Financing (Lazere 1968: at 99). could simply say that as "the warehouse company is a bailee of goods belonging to the borrower and is aware of the secured party's (lender's) interest, [h]ence the possession of the bailee is deemed the possession of the secured party under Article 9 [...] and no filing is required", from today's perspective one ought to make qualifications to this statement. Now, the Revised Version of UCC Article 9, still not defining possession, ramifies the rules of perfection according to the type of "possessible personal property", plus the type of the tangible asset used as collateral; employing the law of agency and bailment to fix the rules.

Since per definition the field warehousing company issues warehouse receipts that are in the eyes of law documents of title, they can be pledged and in modern life it is the pledging of receipts that counts for the purposes of perfection. This is another reason justifying the characterization of field warehousing as the 'progeny' of possessory pledges. However, this does not mean that the earlier elaboration on when is the field warehousing

68 See, e.g., Comment (March 1960): Financing Inventory through Field Warehousing. Yale Law Journal 69(4): 663-708 (hereinafter: Yale 1960 Comment).

69 Yale 1960 Comment at 672-674.

70 Yale 1960 Comment at 672-673.

71 For example, courts did not void arrangements when the borrower's former employee was hired to act the warehouse's custodian until evidence of de facto control was proven. E.g. in Love v. Export Storage Co., 143 Fed. 1 (6 $6^{\text {th }}$ Cir, 1906). Id. note 76 at 673. In Ribaudo v. Citizen's Nat'l Bank of Orlando, 261 F.2d 929, 933-935 ( $5^{\text {th }}$ Cir., 1958) the arrangement was ruled valid (i.e. possession recognized) notwithstanding the constant circulation of debtor's employees and of some visitors in the warehouse as well as the presence of goods that were not covered. Different problems were at stake yet were upheld in Chartered Bank of London v. Chrysler Corp., 115 Cal. App. 3d 755, 758-759, 171 Cal. Rptr. 748, 749-750 (1981): the signs in the warehouse incorrectly stated that all goods were in the 'possession' of the warehouse company. The last two cases are cited by Baird \& Jackson. 
company receiving proper possession is of no relevance. Quite to the contrary, in fact, pledging of warehouse receipts could be accepted as equivalents of pledging the goods they represent only if the possession of the warehouse is impeccable. When the warehouse's possession is less than perfect, however, filing in addition to reliance on constructive possession would be more than sensible; especially in jurisdictions with a low rule of law index or in the freshly reformed systems.

\subsubsection{Field Warehousing as a Policing Device}

In the US, field warehousing presumably survives notwithstanding the changed circumstances because it remains an efficient collateral-policing device. In fact, given that filing in addition to transfer of possession into the hands of the warehousing company for the sake of ensuring full-proof perfection was resorted to only at some points in the long history of field warehousing, it may be claimed that policing of the collateral has been always its main function. The main utility of field warehousing, in other words, rests with policing in the US. This applies a fortiori in emerging systems with a low rule of law index and fledgling financial sector.

Needless to say, however, that field warehousing inevitably imposes transition costs, and it could turn into a too expensive "device to police collateral." (Lacy 1990: 247-457, at 269). For the lender bank the deal is worth of paying the concomitant service fees because it is released from establishing its own warehouse and from the duty of policing the debtor; or doing that by the bank itself would be cheaper. For sure, the field warehouse's services provide a precious safety cushion against the fraudulent behavior of the debtor and allow the reduction of the banks' role to the status of pledgee of warehouse receipts; naturally if the system functions impeccably (Lacy 1990: 148-149).

If the US system is looked upon from outside, a quintessential point is almost invariably neglected: the UCC by abandoning the Benedict rule parted also with the requirement of policing of the collateral as a statutory precondition of the validity of security interests. The practical outcome of what is that now policing is a purely contractual matter: something known, presumed and thus not stressed in the text of UCC or the Comments anymore. To the UCC a security interest will be valid even if the parties have failed to specifically agree on the concrete forms of policing: nothing in the UCC imposes such duty on the parties to secured transactions. Parties may foresee that the secured creditor himself will do the policing but may also entrust that task to third party professionals; including a field warehousing (or collateral certification) company. The obvious advantage of the field warehouse avenue is linked to the professionalism of the warehousing company: they offer a tested, full set of services along with taking over the substantial part of the concomitant risks. The remarkable success of the device in Hungary is to be attributable exactly to this: the various roles the industrial underpinnings play - a neglected yet pivotal factor worth taking a closer look at.

\subsubsection{The Industrial Underpinnings of Field Warehousing Law: from 'Field Pledges' to Institutionalized Warehousing}

Albeit Gilmore and the other renowned authors from the pre-UCC period have dealt with the importance the industrialized nature of field warehousing played, this was always a side-topic of minor importance. Yet field warehousing has become what it is and it could perform, either the perfection (i.e. provision of public notice), or the policing functions properly if undertaken by businesses specialized and licensed exactly for these services. With a degree of simplification, field warehousing is not an ad hoc-type of business that 
should be practiced by anybody. In other words, even though it grew out of mere 'field pledges' - ad hoc lookalikes of institutionalized fields warehousing $-{ }^{72}$ it is key to realize that modern field warehousing in the US is invariably institutionalized. Hungarian law presupposes the same though no empirical evidences could be found whether 'field pledges' have been created in this country at all and, if yes, what their legal treatment is. Apart from the cognitive benefits allowing for better understanding the US history of this device, two further consequences are worth exploring by reformers in emerging markets.

The first relates to the impact of the institutionalization of the field on courts. Namely, the presence of a professional warehousing company evidently affected the position of courts when deciding related disputes. Importantly, courts validated even field warehouse structures with meaningful access of the debtor; be it access to the warehouses located on his territory or the practice of appointing debtor's employees as custodians to run the warehouse. In the US, "it [was] the custom for the field warehousing company to employ as its agent in charge of the field warehouse, an employee of the person whose goods are to be stored." [Emphasis added]. Approaching the same issue from the direction of the warehouseman, in other words, courts were willing to accept the warehouseman's less-thanunfettered dominion over the collateral as a proper perfection method (Trefftzs 1941: at 906).${ }^{73}$ In fact, already the first reported field warehousing case was about the validity of the pledge through possession of the collateral by the employee of the debtor stressing the role of the "special bailee" (Vaughn 1967/68: at 21). ${ }^{74}$ Cases suggest as well that the good faith of the so appointed warehousing managers was presumed. These remain issues worthy of consideration especially in emerging systems given that the cost of employing the third party warehousing company always entails extra costs.

The second linked cognitive benefit is the realization that depending on the degree of control that remained with the debtor, various types of field warehouses could be distinguished even though no test has been developed for that by American courts or by scholars. At one end of the spectrum are field warehouses where all warehousing-related services (i.e. handling of the goods, management of the warehouses, guarding, issuance and handling of warehouse receipts) are performed by the warehouse and its personnel. These might, for the sake of comprehension, be labeled as 'fully-controlled' field warehouses. For example, the regulations and the scarce empirical evidences from the last few years suggest that today in Hungary these seem to be the rule and thus the unfettered dominion on the warehousing company is guaranteed.

72 Although in modern times field warehousing companies should be subjected to prudential regulation with licensing and other imposed requirements, it remains a legitimate legal issue what the fate of 'field pledges' should be if they arise even in highly regulated systems.

73 See, e.g. the definition of the American Bankers' Association from 1941 which read: field warehousing is "a specialized warehousing function accommodating the storage of goods on the owner's premises under the custodianship of a bona fide warehouseman." [Emphasis added]. See the review of three field-warehousing-related books (two from 1940 and one from 1941) by Trefftzs 1941.

74 Sumner v. Hamlet, 29 Mass. 76 (1831). The formulation of the court deserves quoting as it gets to the essence: "To constitute such special possession, it was not necessary that the goods should be removed from the premises of the former owners; it was sufficient that they were so far in the custody of the special bailee, that he could at all times have the legal control of them. [...]." The case is described in Vaughn. (1967/68). 
Browsing the long line of American field warehouse cases could, however, easily reveal that a typical field warehouse was based on less stringent arrangements. The departures were variations of debtor involvement and allowed for debtor control amounting to less than full-unfettered-dominion. Consequently, these could conveniently be named as 'cooperative' or 'less-than-fully-controlled' field warehouses. The descriptions of field warehousing schemes often introduced by the qualifications of 'typically' or 'customary' prove that, indeed, apart from the feature of being located on the premises of the debtor, the other attributes of field warehousing varied meaningfully. The US Supreme Court, already in 1904, in the Union Trust Co. v. Wilson case formulated a test exactly based on these secondary features of field warehousing. In the case, the Court found the arrangement valid exactly because the field warehousing company had "adequate possession," consequent to which the issued warehouse receipts transferred also proper possession on the financier so as to be a valid lien against the bankruptcy trustee (Vaughn 1967/68: at 24). ${ }^{75}$

This unorthodox historic digression deserves attention, at least, for two reasons. On the one hand, based on the above - especially based on the existence of significantly less-thanfully-controlled warehouses - one could posit that the more dominion was left with the debtor, the more was the concrete arrangement closer to a floating lien with the exception of the involvement of the third party professional: the warehousing company. On the other hand, the above typology deserves merit especially for those emerging systems in which fully controlled warehouses are not statutorily mandated. ${ }^{76}$ Namely, in those systems, courts deciding field warehouse cases would be expected to develop a test for determining whether the concrete arrangement and the concrete level of debtor's dominion (involvement) could still be tolerated so as not to invalidate the transaction. The lesson of the long history of US field warehousing is encapsulated in Vaughn's comment on the notorious 1963 vegetable oil swindle (the Salad Oil Scandal): "it probably could not have occurred if absolute physical transfer had been a mandatory requirement." (Vaughn 1967/68: at 24).

\subsection{The Role and the Limits of the Regulatory Prong}

As already stated most of the features and functions of terminal and field warehousing are the same and revolve around storing of the goods used as collateral, issuance of warehouse receipt based on that and pledging of them to get financing from a bank. Consequently, most of the risks are also the same because of why the regulation of the status of warehousing companies must be identical for both forms. It should not come as a surprise that the specific rules applicable to the field version come on top of the common basic regulatory framework.

75 The nearly perfect field warehousing arrangement was made of the following elements: $1 /$ the 'field warehouse' was separated by a wall from the rest of the debtor's property and it was padlocked with the warehousing having the only key to it; 2 / a sign outside the building indicated that it was a warehouse; 3 / each piece of the collateral was marked that it is in the possession of the warehouse; 4/ the debtor could regain possession of the goods making the collateral (leather) only by surrendering the receipts and "having a man come from [the warehouse] to unlock the warehouse."

76 This may be the case, for example, in today's Serbia, where the law knows not of field warehousing and where statutory law's reach is very narrow extending only to public warehouses (i.e., terminal warehouses), which are presumed to act only for warehousing of agricultural goods. The two acts regulating warehouses are the Act on Obligations ("Zakon o obligacionim odnosima," sections 730-748) and the Act on the Public Warehouses for Agricultural Goods ("Zakon o javnim skladištima za poljoprivredne proizvode"). 
While at the time the opinion in the watershed case of Benedict v. Ratner (1925) ${ }^{77}$ was delivered by Justice Brandeis leaving unfettered dominion on the collateral with the debtor imputed fraud and voidness, this doctrine of fraud was abandoned with the UCC. Consequently, UCC Article 9, through its elaborate rules on perfection, now contains solutions against ostensible ownership only. It does not contain a similar elaborate system of rules against the fraud of the debtor, the resolution of what is rather delegated to secured creditors. This includes not just that the employed notice-filing system works on the presumption that the secured creditors are aware of the need and know how to gather additional information on the debtor and the collateral but more importantly that policing of the debtor was completely delegated to them. Secured creditors may do the policing themselves but may also resort to field warehousing as one of the key panaceas against debtor's fraud because this device means divestiture of the debtor of his unfettered dominion over the collateral. In other words, under UCC Article 9 and the Unitary Models combating debtor fraud by way of policing under the UCC is a matter of contract.

It ought to be added, however, that the success and high professionalism of the industry is dependent also on the regulatory tools against the incompetence or fraud of warehousing companies themselves. This is the primary function of regulations which through licensing, bonding (i.e., insurance against liability) and other prudential rules try to ensure that only properly equipped and expert companies enter the warehousing market. For our purposes it suffices to stress here that these play a pivotal role in creating a healthy, highly professional and thus trusted industry in a country and are supplementary to secured transactions laws. With such an image of the industry, it could be expected even in developing systems that the presence of a field warehousing company would be a formula for benevolence of courts - similarly to the above-mentioned US experiences.

Finally, in modern times, when many forms of secured transaction have become linked to the capital and commodities markets, in a world significantly more volatile and thus riskier, warehousing could not escape this fate either. For example, given that grain, the most typical collateral utilized via warehousing financing, is subject to speculation on the derivative markets even in systems with less than developed commodities markets, warehoused goods could not escape attacks of speculators either. As a result, exposed banks may either abstain from financing warehousing or take extra precautions and charge higher interest rates against this additional risk. Hungary, as a relatively small market, is a good proof of the point: as the experiences of the past decade or so showed speculation in times of extreme draughts could heavily hit not just farmers and the linked industries but banks as well. ${ }^{78}$ This idiosyncratic and new-generation pool of risks obviously requires special attention as neither the mechanisms offered by secured transactions law, nor the classical licensing regulations, may prove to be insufficient. Admittedly the in-depth analysis of this specific aspect of financing via warehouses awaits some future times.

77 Benedict v. Ratner, 268 U.S. 353 (1925).

78 See, e.g. the interview with one of the directors of the Hungarian MKB Bank on the prospects of warehousing financing after 2010 in the agricultural magazine Gazda-Praktikum of 30 Sept. 2010 available at <http://saccer-ptipti.blogspot.hu/2010/09/kozraktarozas.html >; last visited on 29 July 2014. 


\subsection{The Supplementary Role of the Law on Warehouse Receipts}

The third prong that plays a key role in the life of warehousing (both terminal and field warehousing) - besides warehousing regulations and secured transactions law - is the law on warehouse receipts. Albeit this body of law in the US is in UCC Article 7 (i.e. distinct from secured transactions law in UCC Article 9), it could hardly be separated from secured transactions law as today financing on the basis of the goods given to the warehouse almost invariably occurs based on the pledging of warehouse receipts.

The inseparability of the two is readily visible already from the US history of warehousing. In fact, the full recognition of field warehousing as a distinct security and financing device was predestined on giving green light to warehouse receipts as well. According to Gilmore, the leading case of First National Bank v. Harkness (Gilmore 1965: 156-157) $)^{79}$ - validating the first rudimentary forms of field warehouse - was insufficient to make warehouse receipts and the possibility of their pledging (documentary pledge) recognized as well. Consequently, "[w]arehouse receipts had to be helped along by statute: the Uniform Warehouse Receipts Act (1906)" (Gilmore 1965: 159), that gave a leg on also to field warehousing, too.

The story does not end, however, here. Obviously, the interposition of the warehouse receipts affects the rules of secured transactions law. Notably, the perfection point is not the transfer of the collateral to the warehouse but rather the point in time when the warehouse receipts are pledged. ${ }^{80}$ What matters is that full exploitation of field warehousing (or terminal warehousing) presumes the existence of proper law on warehouse receipts as well.

\subsection{What can Emerging Systems learn from the US History of Field Warehousing?}

\subsubsection{The Impact of the UCC on Field Warehousing}

The first, pre-UCC era of the history of field warehousing comprised the emergence, the subsequent organic development of the industry and the related law culminating in the Uniform Warehouse Receipts Act in 1905, which "gave [the industry] a recognizable status" through making the warehouse receipt a recognized type of document of title representing the pledged goods (McGuire 1974: at 272). The parallel development of the security aspect was about constant innovation centered on structuring a cost-efficient yet by-the-court acceptable substitute for actual paradigmatic possessory pledge. The process

7942 W. Va. 156, 24 S.F. 548 (1896). The case was decided in the era characterized by lots of dilemmas and experimentation. From today's point of view extreme holding of the case should therefore be approached with that caveat in mind. In fact, the case elevated to the status of a 'leading case' only because it paved the way to the "idea that an effective pledge could be created by appointing the agent, employee or servant of the pledgor to serve as custodian of the goods for the pledgee [though] [i]t was clear [...] that such custodianship was a feeble reed to lean on [...]." Concretely, the court held that a non-public letter containing instructions to a 'resident watchman' to hold as collateral security crude petroleum oil in 'an immense iron tub' by the owner of the oil was an effective pledge and which thus had priority over the Bank's attachment lien.

${ }^{80}$ The US systems allows for all three possibilities: while UCC s. 9-312 (c) deals with perfection of security interests on goods covered by a negotiable document, and subsection (d) if nonnegotiable documents are issued, section 9-313 "governs perfection of a security interest in goods in the possession of a bailee who has not issued a document of title." Quoted from point 7 of the Official Comments to UCC section 9-312. 
could not but lead towards the emergence of a distinct professional industry, which was of key importance for judges deciding on the appropriateness of a field warehousing arrangement and for the overall success of the device. This would be the first lesson to pay heed to. The second, as already these early developments suggest, is that field warehousing cannot develop and properly function without adequate warehouse receipt laws either.

The arrival of the UCC meant, however, more than just the integration of the 1905 Act into Article 7 with modifications. ${ }^{81}$ In fact, the warehouse receipt-part of the saga seems to have been the easier, smoothly subscribed to, side of the same coin. The security aspects of the transaction have caused much more upheaval mainly because of the introduction of filing as the prime perfection method for security interests on inventory and the risk of losing priority over a security interest on after-acquired property perfected by filing. In fact, from this and the linked developments follows the third lesson from US evolution of field warehousing. More precisely, as the UCC placed perfection as the ostensible ownershipcuring method into the center of the system, soon it became imperative to clarify what the Janus-faced nature of field warehousing means. There was hesitation on whether the device is primarily a perfection-method or rather only an efficient policing method?

Not unsurprisingly, the initial reaction of the industry was hostile because the very business of field warehousing was also perceived as "a lien-perfecting device" (McGuire 1974: at 280) something that was conceived as an essential ingredient of the business model, the key source of income. Notwithstanding of that, quite curiously, the subsequent dereliction of filing as a mandatory requirement is to be subscribed to the opposition of the industry (McGuire 1974: at 278). This hesitancy should not be perceived as something idiosyncratic only to the US as it is a key issue that may realistically reappear also in other jurisdictions. Especially in reform systems where in the initial phases characterized by lack of experiences with the device, instead of following the contemporary American rules, perhaps the option of dual perfection might be the right thing to do.

By the 1960s, however, even the industry was forced to realize the negative effects of the new unitary perfection system of UCC Article 9 rooted in the mentioned blurring of concerns on ostensible ownership with fraud. That was roughly the time when some of the players in the market realized as well that field warehousing was not only about that: it was also an efficient method for controlling the inventory serving as collateral. Amidst of a declining market this feature of field warehousing was exploited to survive to this day. As the Lawrence Field Warehousing Company was forced to inaugurate the so-called 'certified inventory control' service (McGuire 1974: at 280), so was the industry expected to innovate and improve its policing capacities. Undoubtedly, the drive to constantly care for upgrading of the employed policing techniques is a fundamental - the fourth - lesson to be borne in mind; something fully corroborated by the much shorter Hungarian history of this device and the increased focus on the quintessential role top-notch policing plays in the regulatory responses.

${ }^{81}$ Besides the Uniform Warehouse Receipts Act, UCC Article 7 contains the consolidated and revised version of the Uniform Bills of Lading Act and some provisions of the Uniform Sales Act on the negotiation of documents of title. The most important omissions are the criminal provisions of these as "[t]hese [...] are inappropriate to a Commercial Code, and for the most part duplicate portions of the ordinary criminal law relating to frauds." Quoted from the Comment to UCC s. 7-101. 


\subsubsection{Field Warehousing as the Functional Substitute of the Floating Lien}

The fourth lesson, or rather an interlinked web of lessons, to be extrapolated from US legal history is related to the relationship of field warehousing and the floating security. In this country, the main reason behind the policy against the floating lien being characteristic for the entire pre-UCC period and the concomitant fears against secret transfers was "the feeling, often inarticulate in the opinions, that a commercial borrower should not be allowed to encumber all his assets present and future, and that for the protection not only of the borrower but of his other creditors a cushion of free assets should be preserved. [...]. "\$2 For this reason it ought to be subscribed to that field warehousing, indeed, came into being exactly to bypass this floating-lien-condemning policy (similarly to such other idiosyncratic US security devices as the factor's lien or the trust receipt). ${ }^{83}$ In Australia, Canada, New Zealand or the UK, which recognized the floating security in the latter half of the $19^{\text {th }}$ century thus there was no pressing economic need for the invention of the local kin of field warehousing. Consequently, the conventional explanation why these countries are devoid of the security device in the center of our observations is essentially correct but incomplete.

This narrative - forming also the gist of the English position - is only partially acceptable as field warehousing as a distinct industry has not disappeared in the US after the appearance of UCC Article 9 validating the floating lien. This fact is another proof that the discourse on the utility of field warehousing should not be reduced to the oversimplified formula of 'either the floating security or field warehousing.' What has changed in the life of field warehousing after the successful spreading of the UCC is that thereafter litigation was not about the validity of field warehousing in general but about other issues like "why not a chattel mortgage?" (Gilmore 1965: at 155) and, in particular, different questions of liability (Gilmore 1965: $§ 6.5$, at 170). Or, as Gilmore put it, "[f]or the sake of convenience [...] 1950 [may be taken] as the date when field warehousing case law moved from the first into the second period, [when] the focus of litigation suddenly [shifted]." (Gilmore 1965: $6.5,169-170)$.

The conceptual base for field warehousing is today of little, if any, relevance in the US as the validity of this security device has not been questioned every since. It is simply being exploited by professional industries who additionally harness what new technologies offer for their own benefit. This fact deserves highlighting because for other jurisdictions being at the beginning of the evolutionary process clarification of conceptual questions tends to be of pivotal importance. This applies especially to Continental European civil law jurisdictions characterized by system thinking and who thus ought to go back and research early $20^{\text {th }}$ century US cases in the quest for answers of that sort. With a degree of simplification, in other words, while for Continental Europeans answering all the conceptual questions is the number one priority, for US lawyers this is only of secondary importance, if at all and at least today.

82 Comment 2 to s. 9-204 of the pre-Revised Version of UCC Article 9.

${ }^{83}$ As the Official Comment 2 to s. 9-204 of the pre-Revised Version of UCC Article put it: "In pre-Code law there was a multiplication of security devices designed to avoid the policy: field warehousing, trust receipts, factor's lien acts and so on. The cushion of free assets was not preserved. In almost every state it was possible before the Code for the borrower to give a lien on everything he held or would have. There have no doubt been sufficient economic reasons for the change." 


\subsubsection{The Five Potential Functions of Field Warehousing}

The fifth lesson relates to the more modalities of the exploitation of field warehousing above its utility as a perfection and policing device already touched upon. Namely, in the US, field warehousing is primarily looked upon as a security and financing device overshadowing its other potential uses. Here we do not mean merely the obvious - storagerelated services - but the warehouseman appearing in the shoes of a direct financer and adaptation of field warehouse to serve as a wholesale (floor-plan) distribution method. In brief, besides providing the storing and inventory-handling services, being a perfection- and a collateral policing method, field warehouses may also appear as financiers and distributors.

Unless specific regulations provide otherwise, ${ }^{84}$ in principle, nothing prevents field warehousing companies to engage in direct financing of borrowers (Gilmore 1965). ${ }^{85}$ This was not unknown in some periods of the US evolution of this warehouse variant, like the end of $19^{\text {th }}$ century 'storage warrant companies', which were first generation "professional warehousemen" (even if differently named) making also loans against the warehoused goods as security (Gilmore 1965). ${ }^{86}$ The issue is naturally whether the field warehousing companies are financially strong enough or are in the position to raise capital under favorable terms and conditions. In emerging markets, theoretically this may be a proper avenue for financing of agriculture especially. It makes thus sense, as it is the case in Hungary, ${ }^{87}$ to explicitly regulate also this activity of warehouses.

Talking of distribution, even though terminal warehousing was primarily used for storage and distribution, and field warehousing has been looked upon as a financing device, ${ }^{88}$ the ingenious mind of commercial lawyers has devised ways also to exploit it as well in the wholesale process. The so-called secured distribution' or 'secured trade credit' of high popularity around 1960 may be a perfect example the essence of which was employment of field warehousing to for extension of trade credit to dealers by manufacturers especially of goods having a seasonal demand. In other words, "[while] the manufacturer

84 Needless to say, unless specifically exempted, field warehousing companies extending credits would most presumably be caught by banking regulations, which would entail not just licensing, high capitalization, capital adequacy, risk management and other rules but also heavy oversight by the banking supervision. The most prudent approach would be to synchronize the sector-specific and banking regulations.

85 Albeit nothing prevented field warehouse companies from serving also as financiers, yet as Gilmore noted, up until the mid-20"th century "[t]ypically ... the field warehouseman is a specialist who performs only custodial services with respect to the warehoused goods." See Gilmore 1965: at 148. Likewise, only the different nature of finance companies could be attributed that they have not made use of the services of field warehousing companies: predominantly thus field warehouses served the interests of commercial banks. See Gilmore 1965: at 148.

As indicated by Gilmore, in 1960 the number of field warehouses was estimated to be around six thousand, the overwhelming $(95 \%)$ of which was operated by only six large companies led by the Lawrence Warehouse Company. Gilmore 1965: at 147.

86 See Gilmore 1965: $§ 6.3$., at 159 . For a list of cases with field warehousing companies making also advanced to the depositor see Gilmore 1965: § 6.2., at 147.

87 See sections 28, 28A and 28B of the [Hungarian] Act on Public Warehousing of 1996, which provides, for example, that the public warehouse (including also its field variant) may "extend secured loans up to the 2/3 of the value of the pledged goods to the possessor of the warehouse receipt, so that that loan to a single client, or client group, cannot be more than the twenty-five percent of the capital of the warehouse." Ibid. s. 28(1).

88 See, e.g. Yale 1960 Comment: supra, note 88, at 663. 
retains effective control of the warehouse's contents, under the policing of an independent third party, [...] the dealer has ready access to the goods as soon as he is in the position to pay for them" (Friedman 1942: at 991). ${ }^{89}$ This particular service survived in the US to present day. ${ }^{90}$ In brief, field warehousing could also be looked upon, or its equivalents could be sought in other countries, from among wholesale (floor-plan) financing devices.

\section{FIELD WAREHOUSING OUTSIDE THE UNITED STATES}

\subsection{United Kingdom}

Albeit discrepancies do exist between English and Scottish law, the essence is shared: field warehousing has waned away parallel with the growth of the floating charge by the first half of the $20^{\text {th }}$ century (Ellinger-Lomnicka-Hooley 2006: at 801)..$^{91}$ As a result, account on field warehousing is consequently incomplete as no practical needs required exploration of whether floating charge - or the "non-possessory fixed charge [which] could be obtained by requiring the dealer to secure the prior asset of the finance house to every sale transaction" (Ellinger-Lomnicka-Hooley 2006: at 797) - have completely substituted field warehousing or whether the co-existence of the two might have beneficial economic effects? The rare retrievable sources succinctly ascribe the lack of field warehousing to the 'artificiality involved in the arrangement' and the preferences of commercial banks (Ellinger-Lomnicka-Hooley 2006: at 802). The occasional equally laconic glosses on field warehousing in Australian, Canadian and the papers of scholars from New Zealand (if any), essentially repeat the English position (McKendrick 2010: note 13 on page 784) ${ }^{92}$ notwithstanding that they have subsequently taken over the unitary and comprehensive secured transactions law model enshrined in UCC Article 9.

\subsubsection{The English Argument: Field Warehousing as a Substitute of the Floating Charge}

The main English explanation for the lack of field warehousing rests with the fact that floating charge leaving unfettered dominion in the hands of the debtor has been given green light already with the Holroyd v. Marshall case in 1862. As opposed to that, the doors

89 See Yale 1960 Comment: Ibid. at 695. See also Friedman 1942.

90 The US 'Collateral Certification Services' LLC, operating nationwide, for example, specifically offers also the services of 'secured distribution.' See at $<$ http://www.collateralcert.com/ applications.html >; last visited on 29 July 2014.

91 See the historic cases of Young v. Lambert (1870) LR 3 PC 142; Hilton v. Tucker (1888) 39 Ch.D. 669; or Wrightson v. McArthur and Hutchinsons (1919) Ltd. [1921] 2 KB 807 listed EllingerLomnicka-Hooley 2006. Albeit the authors $I d$ speak of the 'method' of field warehousing having a "long pedigree," the mentioned cases seem to be rather only remote kin of US field warehousing and are based on cases coming not only from England (e.g., Young v. Lambert is a Canadian case from Quebec).

${ }_{92}$ Most forcefully formulated by Roy Goode stating that "[t]he development of field warehousing in the United States was powered by the refusal of American courts to recognize the validity of non-possessory mortgage of inventory on the ground that this was a fraudulent conveyance, since the debtor retained dominion over the property. [...]. [Moreover,] American law never adopted the English floating charge; either the security was a valid specific charge, albeit over shifting security (and this is the meaning of the American 'floating lien'), or it was invalid and conferred no real rights on the creditor. [...]." [Emphasis added]. See McKendrick 2010. 
before floating lien were completely opened in the US only with the UCC and its abandonment of the Benedict rule only in the 1950s. This was acknowledged also by Gilmore, who noted that "[t] he state of almost intolerable complexity which [US] security law reached by the end of the [19 $\left.9^{\text {th }}\right]$ century was not matched in England" (Gilmore 1965: $\S 2.1$, at 25-26). As both devices allow for the use of inventory as collateral, the two admittedly share this important commonality and to this extent the English position could be subscribed to. However, albeit it is true that the drive - lasting for almost a century in the US - aimed at finding an acceptable substitute for the floating charge was a genuine catalyzer of developments in the realms of secured financing, this process cannot be attributed solely to field warehousing but the same could be claimed also for the other preUCC independent security devices, too.

In other words, no sign of equation should be placed between the English floating (or fixed) charge and the American (or other similarly structured) field warehousing because they significantly differ (Wood 2007: at 786). ${ }^{93}$ First of all, while the floating security requires leaving unfettered dominion over the collateral (all present and future assets) with the debtor, field warehousing per definition presumes exactly the opposite - transfer of possession (over some specific part of the debtor's inventory) into the hands of a third party professional. Second, perhaps the most persuasive argument and living evidence at the same time is that field warehousing has survived in the US and has spread in countries like Hungary notwithstanding the presence of the floating security. In other words, as the experiences of these countries prove, floating securities and field warehousing are hardly mutually exclusive. Notwithstanding of what, as opined by Roy Goode "there is no indication that [field warehousing] will ever" take root in England. The differences, however, do not negate the English position vouching for the existence of a functional kinship between the two devices.

Yet besides the floating charge-field warehousing narrative, obviously other factors have also contributed to the different course of developments on the two sides of the Atlantic and for a gradual and differing partition with the initially common absolute rule of the Twyne's case. In England, as a seaborne country and as dictated by the unprecedented growth of sea-trade, the partition with the Twyne's rule and exploitation of warehouses occurred earlier. For example, the establishment of the West India Dock Company in 1803 "primarily designed to facilitate the storage of goods awaiting shipment and to house the large quantities of imports" (Vaughn 1967/1968: at 7) is due also to the invention and issuance of the first dock warrants. The new practices first lead to litigation in which judges applied by analogy the rules on bills of lading (Vaughn 1967/68: at 12) but were, similarly to their American peers, disinclined to bend to the wishes of the industry. The industry has, however, eventually prevailed through the passage of the Factor's Act (1889) and the Sale of Goods Act (1893), which formally recognized warehouse receipt transactions (Vaughn 1967/68: at 14). As opposed to that, warehouse receipts have become fully accepted and widely utilized in the US only after the 1906 Uniform Warehouse Receipts Act though its

93 As Wood put it "[T]he development [in the US] follows the same path which flowed from the notorious bills of sale acts in Britain in the nineteenth century which effectively made secured lending over receivables and inventory to individual entrepreneurs in England impracticable, thereby leading to the proliferation of hire purchase, financial leasing, and the factoring of debts. However, in England this ludicrous regime (which still exists to this day) applies only to individuals and never applied to companies so that the universal corporate charge was able to take off entirely free of these inhibitions." 
negotiability had been recognized by numerous States already in the latter half of the $19^{\text {th }}$ century. ${ }^{94}$ In other words, warehousing and the law on warehouse receipts grew with a significant delay in the US, which has obviously also contributed to the discrepant path of evolution.

Another important distinguishing factor was the recognition that retention of possession is not per se something fraudulent. This rule was blessed in England already in 1832 with the Martindale v. Booth case; ${ }^{95}$ a path on which the next stage was the passage of the Bills of Sale Act in 1854 that introduced registration of chattel mortgages within 21 days. This process then peaked with the recognition of the floating charge allowing the use of raw materials and inventory as collateral. As opposed to the British favorable reaction, even though chattel mortgage statutes providing for registration also began spreading from east to the west already from the 1830 s on, US courts "held the statutory validations within the narrowest possible limits, and in so doing hampered the effective use of the chattel mortgage" (Vaughn 1967/68: at 15). ${ }^{96}$ This hostility in particular was manifested in refusal to validate mortgage of stock in trade because chattel mortgage was expected to be specific. Eventually the solution for what then was found outside mortgage law in the form of independent security devices like the trust receipt, consignment or field warehousing (Vaughn 1967/68: at 16). ${ }^{97}$

\subsubsection{The Neglected Saga of Agricultural Charges}

A further point has to be added though to the above explanation as one of our starting points, triggered by the recent Hungarian developments, was exactly what security devices are exploited when agricultural products are used as collateral. In the US, to stress immediately, field warehousing was, indeed, used also but not exclusively to finance agriculture (Friedman 1942; Gilmore 1965), ${ }^{98}$ from using cattle (Barnes 1988: at 337) ${ }^{99}$ and other agricultural products as collateral. The logical query is then what security devices were used to deal with the same set of problems in England or Canada; jurisdictions not knowing of US-style field warehousing to this day? This is a legitimate question especially because fixed and floating charges are available only to finance companies and not individual traders or unincorporated business vehicles yet which are typical business forms

94 Just like in case of chattel mortgage legislation, New York was the first to statutorily validate the negotiability of warehouse receipts in 1858 , followed by Pennsylvania in 1866, Kentucky in late 1860s, Illinois in 1871, New Jersey in 1881, with Idaho and North Dakota following the suit in 1891.

953 Barnwell \& Adolphus's Rep. 498 (1832). Id., at 16.

96 See Vaughn: $I d$. at 15.

${ }^{97}$ See Vaughn: Id. at 16.

98 Agricultural products were, however, not the only and the main types of goods financing through field warehousing though as Friedman noted in his article from 1942 "[a]lmost any kind of commodity can serve as the basis for a loan." See Friedman 1942: at 993. In fact, most authors seem to take the canning industry as the paradigm industry making use of field warehousing. However, in the US, preferences have changed over time. Besides the end of $19^{\text {th }}$ century storage warrant companies' that were specialized in iron and steel, the "[o]ther commodities which appear[ed] in the early cases [were] wool, paper, seeds, leather and lumber." See Gilmore 1965: § 6.3., at 161.

99 See, e.g. the article of Barnes from 1988 discussing the case First National Bank of Minneapolis v. Kehn Ranch, Inc., 394 N.W.2d 709 (S.D. 1986) in which a security interest was granted "in cattle, feed, crops, and equipment." Barnes 1988. For a more recent example see Kehn Ranch, Inc. v. Milbank Mutual Insurance Company, 394 N.W.2d 709, in which the Ranch secured the bank's loan by "cattle, feed, crops, and equipment of the Ranch." 
in agriculture (Ellinger-Lomnicka-Hooley 2006: at 782). Hence, while the justification that floating charge is the substitute of field warehousing is valid in case of incorporated companies, in case of non-incorporated business vehicles in agriculture and in other business sectors, one has to look for additional explanations.

These seem to rest on two pillars in the UK: the various government backed institutions and programs aimed at incentivizing and easing financing of farmers and their associations and the special category of agricultural charges. As far as the first is concerned, suffice to say that many emerging markets would even today envy the UK for the "few" agriculturesupporting initiatives from the beginning of the $20^{\text {th }}$ century (Minty 1930: 249-258), ${ }^{100}$ which have undoubtedly eased the financing of agriculture. As government sponsored projects targeting financing in the agricultural sector are not unknown in emerging markets anymore, they prove that these cannot be pointed at, with or without company charges, as full-scale alternatives to field warehousing. This much suffices for our purposes on this.

The issue of agricultural charges is another issue, which leads us to the Agricultural Credits Act 1928. The Act foresees explicitly that fixed and floating charges, though subject to somewhat different rules compared to company charges (Minty 1930: at 250), ${ }^{101}$ could be granted by "farmers [who could be organized as sole traders ... a partnership but not a corporation] [...] to a [registered deposit taking Bank.]."102 These tailor-made charges already are more up to the point yet as they behave essentially as their company kin and do not substitute the factual, policing component of field warehousing, they could not be but another stone in our still incomplete mosaic. In brief, the question remains what substitutes field warehousing in case of high-risk farmers and agricultural enterprises when agricultural charges would be insufficient to properly police the debtor?

\subsubsection{The Distinguishing Features of Scottish Law}

Floating charges were introduced in Scotland by the Companies (Floating Charges) (Scotland) Act 1961, in effect adopting the English system though without fully integrating them into the system (Gretton 2003: at 332). ${ }^{103}$ As a result, the two laws are almost identical; of relevance to us is in particular the rule on the non-availability of the floating charge in case of individual and non-incorporated entities as debtors.

Following the impetus of the Agricultural Charges (England and Wales) Act of 1928, Scotland has also introduced a substitute for the context of agriculture by the Agricultural

100 For a description of such pre-1930 institutions and projects e.g. the Lands Improvements Company, the Farmers' Land Purchase Company (1920) or the Agricultural Mortgage Corporation and the reasons leading to the enactment of the 1928 Act see Minty 1930.

101 One interesting example relates to making public information on agricultural charges. Namely, even though the perfection of these charges presumes registration earlier with the Land Registry and nowadays with the Agricultural Credits Department (Plymouth) publication of particulars of agricultural charges an offence (section 10). The reason was that the charges resembled bills of sale which were the main security for short-term loans in the times preceding the passage of the act and which "in England, carri[ed] with it a certain degree of social stigma analogous to bankruptcy which [did] not attach to the granting of a chattel mortgage in the U.S.A> or similar charge on movables property in other countries." See Minty 1930.

102 See the definition of 'farmer' and 'Bank' in section (7) of the Agricultural Credits Act.

103 See generally Gretton 2003 As Gretton put it, "[t]he Scottish floating charge has been a success, if the criterion of success is widespread use. [Yet] [i]t is not a story of a mixed system receiving an institution of English law and triumphantly integrating it." 
Charges (Scotland) Act of 1929. More or less self-explanatory, this security device can be constituted only on "stocks of merchandize;" contrary to floating charges in case of which there is no such limitation. ${ }^{104}$ Albeit initially subject to registration, later that requirement was abolished in $2001^{105}$ and consequently nowadays even the Law Commission admits that no information could be collected on whether and how many such charges exist. ${ }^{106}$ To make things worse, these charges cannot in fact be enforced because the obsolete and nonharmonized enforcement and bankruptcy laws. ${ }^{107}$ What matters for our purposes is that presumably, similarly to England and Wales, field warehousing had not emerged in Scotland because of the availability of floating charges and especially agricultural liens. Scottish legal history adds another puzzle to our query because this is only a partial answer: floating charge dates back in Scotland to 1961 and not to the period preceding it. Hence, it remains unanswered what was, if anything, the substitute of field warehouses outside the context of agricultural finance before the arrival of floating charges to Scotland in 1961?

\subsubsection{The Unsuccessful Debut of Field Warehousing in Canada}

Canada is from the perspective of our topic and generally secured transactions law an interesting country because it was under the influence of both English and, especially from the 1960s on, US law. The shift ensued for economic reasons, including the growing presence and influence of US businesses. The rapprochement, however, has not affected all industries exploiting secured transactions law equally. The scarce sources, only mentioning obiter rather than discussing in depth, suggest that, for example, field warehousing has failed to set a solid foothold on Canadian soil, though a 2009 FAO-EBRD material claimed that it has "played an important role in the financing of agriculture in the United States and Canada until the early 1950s" (Höllinger-Rutten-Kiriakov 2009: at 7). [emphasis added] and the arrival of the UCC. Contrary to the claim of this, it seems rather that in the later years of the 1950s field warehousing was "only beginning to take hold" (LeDain 1956: at 99), which has not changed substantially for the next decade or so as Canadian public warehouses were disinterested and only the US Lawrence Warehousing Company managed to open a few. ${ }^{108}$ In the 1980 s, MacDonald still complained of "[t] he absence of a general

104 See section 5 of the Agricultural Charges (Scotland) Act of 1929 Act.

105 The registration requirement was given up by the Financial Services and Markets Act 2000 (Consequential Amendments and Repeals) Order 2001. Interestingly, as for example the Scottish Law Commission noted, it is unknown why such a decision was made given that in the UK secret liens are undesirable as a common policy position. See point 6.21 of the Scottish Law Commission's Discussion Paper No. 151 on Moveable Transactions (2011), available electronically at $<$ http://www.scotlawcom. gov.uk/law-reform-projects/security-over-corporeal-and-incorporeal-moveable-property/>; last visited on 23 March 2014.

106 See point 16.80 of the Scottish Law Commission's Discussion Paper No. 151 on Moveable Transactions (2011), available electronically at < http://www.scotlawcom.gov.uk/law-reform-projects/ security-over-corporeal-and-incorporeal-moveable-property/ >; last visited on 8 April 2013. The document defines agricultural charges as "A security under the Agricultural Credits (Scotland) Act 1929. It is a non-possessory security over the inventory (including after-acquired inventory) of certain co-operative agricultural associations."

107 See the Scottish Law Commission's Discussion Paper No. 151 on Moveable Transactions (2011), point 6.21.

108 See the master's thesis of Gibb I.D.M. (1968): The Farm Management Loan as it Relates to Commercial Agriculture (Univ. of Manitoba, Febr. 1968), at 152 et seq. Text available electronically at < http://mspace.lib.umanitoba.ca/bitstream/1993/8528/1/Gibb_The_Farm.pdf $>$; last visited on 18 
security device that can be readily adapted to the financing of inventory" (MacDonald 1984: at 153). His claim deserves merit even though he was referring to the province of Quebec only and having the variations among provincial laws in mind.

As in the UK, in Canada as well, more reasons should be attributed to that field warehousing has not become a major success from the general availability of the floating charge, the different structure of the economy, high rule of law, governmental involvement in easing the financing problems in agriculture through some other specific reasons. As this is not a place to discuss these issues in detail, two points will only be briefly made. The first relates to the enormous role elevator companies have played in agriculture (especially Western Canada), similarly to the US. These public storages, some owned by the farmers themselves, ${ }^{109}$ made resort to field warehousing (at least to certain extent) unnecessary by being close to the farmers and by making use of negotiable warehouse receipts for financing purposes possible (Golob-Farrell-Orchard (eds.) 2002-2004: at 425).

The other factor having influenced the evolution of inventory financing in Canada has been the different banking system. Contrary to the US, here banks have always had a bigger share of the market and have had thus more substantial leverage to influence in which direction the wheels of change will run. This powerful position coupled with the widespread use of the floating charge has "effectively locked out other asset-based lenders" (Rutberg 1994: at 120). ${ }^{110}$ Even though banks were limited by various means to enter the secured lending market in both countries, the critical point is that the role of banks has always been significantly different in the two countries which obviously affected the evolution of secured finance. In the US, the best example is factoring though roughly until 1963 (Rutberg 1994: note 50, at 39). ${ }^{111}$ In Canada, from the perspective of field warehousing, of crucial importance was the Canadian federal Bank Act that for quite some time imposed limitations on chartered banks (Ziegel 1963: note 6, at 57) ${ }^{112}$ and which even today is being criticized by some renowned scholars as antiquated.

March 2014. The author of the thesis, in fact, recommended field warehousing as an innovation for financing cattle feedlots. Ibid. at 152 .

109 See, e.g. Saskatchewan Heritage Foundation, Saskatchewan Grain Elevators - A Brief History of the Grain Handling Industry (2006), at 29. Document available electronically at $<\mathrm{http} / / /$ www.pcs.gov.sk.ca/GrainElevatorStudy >; last visited on 29 July 2014.

110 The book's succinct formulation deserves quoting: "A significant commercial finance industry never developed in Canada because Canadian banks have pretty much cornered the assetbased lending business. There is no such thing as an unsecured bank loan for any middle-market Canadian company. While some of the publicly owned giants might qualify for unsecured credit in Canada, when dealing with middle-market companies, Canadian banks take liens on all the receivables, inventory, real estate, equipment everything of value. They also take personal guaranties of the principals and, where available, mortgages on their homes. Thus, the banks have effectively locked out other asset-based lenders." Although this quotation related primarily to factoring and lending based on using receivables as collateral and were made twenty years ago, they properly explain and highlight the different position of banks versus asset-lenders in the two countries.

111 The door to factoring was opened to national (i.e., federally chartered) banks due to the changed rules of the Comptroller of the Currency in 1963. Until that point in time only two statechartered banks were engaged in factoring, the Trust Company of Georgia and the First National Bank of Boston.

112 Jacob Ziegel mentioned two such important limitations: prohibition of chartered banks from lending money on the security of goods and security on durable goods could be taken only from a manufacturer. 


\subsection{Organic Growth of Field Warehousing in Hungary: The Winding Road to Success}

\subsubsection{Brief Account of the History of Hungarian Field Warehouses}

Hungary's modern time evolution of warehousing should be divided into three main phases: the early capitalistic era lasting until the end of World War II, socialism lasting roughly until 1990 and finally the post-1990 years of transition and new market economy. The key dates and developments were the following. The Commercial Act of 1875 should be taken as the first milestone as it regulated public warehousing and warehouse receipts (Kelényi 1994: at 7). ${ }^{113}$ Though it was not financial problems but rather the famine of 1863 that seems to have been the key trigger showing how important it is for a country to have a system of warehouses for storage for crop (Szász 1994: at 5). Exact data are hard to find from the pre-1945 period yet it may be presumed that warehousing as a security device had been quite widely exploited. For example, right before WW II there were altogether 204 warehouses (though not all performing public warehousing) (Szász 1994: at 5). As in the post-1990 period, the statutory recognition of constructive pledges and thus a local version of field warehousing was driven by financing needs of agriculture and the introduction of 'agricultural mortgages' ("gabonajelzálog”) relatively late, in 1930 (Szladits 1942: at 805 et seq). ${ }^{114}$

As one of the first steps of socialism (essentially lasting from the end of WW II until 1990) seeing in credit, capital markets and the linked institutions ideological enemies besides banks warehouses were also nationalized and integrated into various other sectors. The love-hate relationship of politics and warehousing determined also what has happened to warehouses yet issuance of warehouse receipts became a possibility only from 1979 on thanks to the increasing leniency of 'Goulash-socialism' not necessarily seeing enemies in all institutions of the market anymore (Szász 1994: at 6) until which year warehouses were essentially used only for storing of the state reserves. Notwithstanding the loosening grip of the system during the 1980 s, it could be validly claimed that the role not just of financial organizations but also of warehouses was degraded to the minimum and innovation that could have eventually lead to the appearance of field warehousing was hardly imaginable.

The real change occurred after the country has redirected its development again towards market economy roughly after 1990. As a country one of the economic engines of which is agriculture, the problems with financing of the sector became visible soon. The denationalization of land further intensified the problem. These reasons made return to the basics to the 1875 Act and to public warehousing inevitable. Public warehousing was conceived and regulated already by the 1875 Act that was revived in 1990 (fall of socialism) and remained in force until the passage of the 1996 statute. From this $19^{\text {th }}$ century act on warehousing was reckoned with also as a quintessential financing method. Suffice to

113 See Title Six, §§ 434-452 of the Commercial Act No. XXXVII of year 1875 ("1875. évi XXXVII. törvénycikk kereskedelmi törvény"). The Belgian act of 1862 and that of Basel from 1864 were used as models.

114 See Chapter II ( $\S 15-34)$ devoted to agricultural mortgages of the Act No. XXII of year 1930 on the Measures Necessary for the Sale of Certain Cereals (in Hungarian: "1930. évi XXII. törvénycikk egyes gabonanemüek értékesítése érdekében szükséges intézkedésekröl”). Section 15 of the Act provides that the listed types of short-term loans, under certain statutorily defined terms and conditions "...the [agricultural] collateral may remain in the hands of the pledgor when the actual transfer of possession is substituted by a symbolic transfer.” [In Hungarian: “... a zálogtárgy az elzálogositó birtokában marad s a zálogtárgy valóságos átadását jelképes átadás pótolja. (Gabonajelzálogjog)."]. See also Szladits 1942. 
mention two features of the 1875 act to realize that: on the one hand, issuance of warehouse receipts was mandatory to chartered warehouses and, on the other hand, warehouses were treated as financial organizations resembling banks like imposition of a high registered capital requirement. Interestingly, the 1875 Act saw in public warehouses primarily financiers and explicitly foresaw that they could extend advances up to two-thirds of the value of the deposited goods; ${ }^{115}$ a position kept also after 1990. The "warehouse as a financier' position could not be maintained by the end of the $20^{\text {th }}$ century as banks have by then become the main players in the world of finances and the 1996 Act was already based on this presumption. Furthermore, it is this Act to which field warehousing should be linked.

\subsubsection{Present Time Hungarian Law on Field Warehouses}

Hungarian law on warehousing with particular explicit rules on field warehousing is today located primarily in the Warehousing Act of 1996 (as amended in 2013), a detailed, pretty technical direct source of law. As Hungary is a monist civilian legal system in which, at least theoretically, and as therefore the Civil Code is the hierarchically most important source of private and commercial law, it must also be added to the list. Yet as warehousing is not recognized by the Code as a nominated contract, one could point only to the few quite general provisions on constructive pledge, ${ }^{116}$ deposits ${ }^{117}$ and on securities, ${ }^{118}$ as well as the provisions containing generally applicable rules that may fill the gaps (if any) left by the Warehousing Act as lex specialis. It is fair to claim, however, that the Civil Code would come into picture primarily in case of disputes. Given that civilian laws do not know about a compact, self-standing bailment law, provisions with similar content are scattered over the law on deposits and secured transactions. ${ }^{119}$

As the rules on possessory pledge have essentially remained intact by the three waves of secured transactions reforms, a researcher looking for detailed perfection rules similar to UCC s. 9-312 or 9-313 might be surprised not to be in the position to find any. This is to a great extent due also to two facts: the lower frequency of conflicting security interests in Hungary compared to the US and the statutory rule according to which only negotiable warehouse receipts may be issued by warehouses, which is otherwise a statutory duty. The a-typicality of conflicting security interests could be ascribed to the linkage of field warehousing to agriculture in Hungary and to the dominance of financing by universal banks. Banks being in the position to control the market were simply not willing to extend

115 See $\S 436$ of the 1875 Act.

116 In the new Civil Code of 2013 see in particular $\S 5: 88(b), \S 5: 89(2)(b), \S 5: 94, \S 5: 101(2)$, and $\S \S 5: 106$ (use of collateral) and 5:107 (protection of collateral).

117 Deposits ("letéti szerzódések") are regulated by Chapter 18 (XVIII) of the new Civil Code (2013). Warehousing is not mentioned specifically.

118 The new Civil Code (2013) regulates securities in Part Five, Title XXIX ( $\S$ 6:5656:578) in a very general manner thus the chances of the supplementary application of these rules are the lowest. Note that in Hungary, similarly to many civilian systems, the Code term and notion of 'security' ("értékpapir") is broad and extends to the UCC categories of negotiable instruments, documents of title and investment property.

119 E.g. § 5:106 of the new Civil Code (2013) invoking also the rules on deposits is the equivalent of UCC s. 9-207. While this section itself imposes the duty of "use of reasonable care in the custody and preservation of collateral in the possession of the secured party [of UCC s. 9-207(a)," the rules on the use of proceeds of the collateral as additional security (UCC s. 9-207(c)) are already in the part on deposits, $\S 6: 361$ of the new Hungarian Civil Code. 
credit on the basis of a floating lien potentially extending also the warehousing agricultural products. At any event, the field warehousing related few reported cases suggest this outcome. Things may though change given that the need for financing is non-abating, financial innovation and taking over western novel business patterns is far from being unknown in the country and thus nothing excludes the possibility of employing field warehouse for distribution purposes ${ }^{120}$ or the increased instances of conflicting securities.

The Warehousing Act is primarily a regulation in the sense that it imposes mandatory licensing rules, regulatory oversight ${ }^{121}$ and sanctions on the industry. These seem to include typical mechanisms from higher capitalization requirements, mandatory insurance through bonding requirements. However, the Act also regulates the parties' rights and duties to warehousing contracts (including the liability of the warehouse for damages), ${ }^{122}$ warehouse receipts and the warehouses' right to engage in lending. In the light of the scandals from the past decade or so, the two main goals of the 2013 amendments were imposition of further safeguards to increase the financial health of warehouses ${ }^{123}$ and forcing of the industry to employ latest generation technological innovation. ${ }^{124}$

The main conclusions that should be drawn from the Hungarian experiences, most directly applicable to emerging markets, are the following. Firstly, hardly could meaningful advancements be made related to the often-cited policy goal of increasing access to finance in emerging markets (the most important sector of which typically is agriculture) based on a section or two on possessory pledge and its twin sister constructive pledge. These clearly are insufficient for the emergence of a professional warehousing industry including eventually also field warehouses and adequate prudential (licensing) rules should parallel be

120 It is no more than sheer speculation yet as the new Civil Code has transplanted the common law concept of 'trust' to Hungary, theoretically nothing excludes the appearance of trust receipts-like secured transactions. As trust receipt has never been known in this country and the drafters of the secured transactions part of the new Civil Code have not had this particular security device in sight when drafting the new Code, similarly to the US, trust may be resorted to by innovative counsel exactly to bypass the registration-based secured transactions system. This may involve also goods in a field warehouse. The new institution is regulated in Chapter 43 (XLIII) $\S \S 6: 3106: 330$ of the new Code and is named "bizalmi vagyonkezelési szerzödés" (the descriptive designation roughly: contract for fiduciary handling of property).

121 The primary regulatory body overseeing the sector is the "State Supervision of Public Warehouses' ("közraktári felügyelet”) [website with English page at < http://mkeh.gov.hu/ kereskedelmi/kozraktarozas_felugyelet >]. The Hungarian Financial Supervisory Authority (supervising also the sectors of banking, insurance and capital markets) has, however, also a say when deciding about the revocation of the license to engage in secured lending. See § 9(1) of the 2013 Warehousing Act, amending $\S 10(1)(e)$ of the 1996 Act, according to which secured lending activities may be prohibited with the consent of the Financial Supervisory Authority.

122 See sections 22-23 of the 2013 Warehousing Act.

123 For example, $\S 1$ of the 2013 amendments of the Warehousing Act, adding three new subsections to $\S 1$ of the 1996 Act, in sub-section (7) specifically foresee that "it qualifies as a high risk warehousing if the value of the deposited goods with a single-location field warehouse, as indicated on the respective warehouse receipts, amounts to the double of the registered capital of the warehouse."

124 Thus, $\S 19$ of the 2013 amendments of the Warehousing Act, adding the new $\S 20$ /A foresees that from $1^{\text {st }}$ of January 2017 the surveillance and safeguarding of collateral deposited with any and all field warehouses must be undertaken by way of electronic property protection systems ("elektronikai vagyon védelmi rendszer alkalmazásával"). 
enacted. Secondly, perhaps the key lesson is that - and this is where both comprehensive and sector-specific reforms have failed - policing should be given equal if not heightened attention. The Hungarian swindles properly prove that neither the comprehensive secured transactions reforms, nor the sector specific regulations were sufficient to forestall these. The 2013 amendments of the Warehousing Act point in the right direction to emphasize the importance of policing. However, no such electronic device has so far been invited which could not be abused or otherwise avoided; hence, the know-how of policing hardly is losing its importance. This, however, must not mean introduction of a Benedict-like ritual, though in case of extremely high risk environments even that should not be a priori excluded.

\subsubsection{The US Salad Oil Swindle Repeated or the Price of not Heeding to the Experiences of Others}

What the post-1990 experiences prove is that field warehousing appeared and became a real yet by legal scholars hardly spoken of success both because of the banks' interest in financing agriculture and as a suitable technique against fraud of debtors. Yet even this relatively brief period of time was filled with ups and downs. The leading case of Léta coop $K f t$ resembling the notorious US Salad Oil case from 1963 is illustrative of the main malady of warehousing: no matter which version of warehousing was resorted to none of them offered a foolproof tool against the fraud of the involved parties. In the case, about eight thousand tons of rice has disappeared worth several billions of HUF. ${ }^{125}$ Banks naturally are reluctant to speak of these fiascos yet they have become as a result more cautious in checking debtors' credit standing and limiting the credit to eighty per-cent of the value of the goods.

Regulators have reacted by increased regulatory scrutiny thereby reducing the market to four players in 2010 and to three in 2012. The information on the abuses made lawmakers realize that much more is at stake than a few isolated fraud cases. As a result of the consensus, spring 2013 saw robust regulatory changes aimed at ensuring that only tested entities enter the warehousing market.

\section{CONCLUSIONS OR WHY IS THE RENEWED FOCUS ON FIELD WAREHOUSING JUSTIFIED?}

\subsection{The US Perspective: On why is US Field Warehousing Law of Bigger Relevance to Emerging Economies than to the US?}

Cognitive and economic reasons prove that the US law and the rich experiences with field warehousing should not be doomed to the dustbin of history irrespective of its declining economic role in the country of its origin. This applies especially to the comprehension of the fundamental role 'institutionalized' field warehousing played in the heydays of the industry culminating somewhere in the 1960s. The label expresses not only the heavy

125 See, e.g. Ezer sebböl vérzik a közraktározás [Public Warehousing Bleeding from Thousand Wounds], in: 15 Nov. 2010 issue of Népszabadság Online Hungarian daily, no author indicated. Available electronically at $<$ http://www.trademagazin.hu/piaci-hirek/ezer-sebbol-verzik-akozraktarozas.html >; last visited on 29 July 2014. 
monopolization of the market (Gilmore 1965: $\S 6.2$. at 147$)^{126}$ but also the fact that these arrangements were conducted by, for these services specialized, duly licensed professional businesses that developed over time highly standardized arrangements. For US scholars this was something commonly presumed and something "natural" as, indeed, eventually this became the norm; no wonder then that this facet of the phenomenon has escaped attention of scholars. One obvious lesson from this is that emerging systems should strive towards the same outcome through licensing and other regulatory mechanisms.

Institutionalization is important, however, not only as a token of proper perfection and professional policing of the collateral. It is both a precondition and the outcome of licensing and regulation of warehousing because only professional, properly equipped and expert businesses should be given the license to provide these services, a precondition that is through licensing - made clear to the participants of the market. This is also the token of a trust in the industry. The third inevitable prong is a proper law on warehouse receipts that elevated to the status of a document of title and backed up by rules allowing for ease of their negotiation would make financing via field warehouses cheap and attractive. The formula is that banks will be more willing to enter into crediting based on pledged warehouse receipts issued by licensed, professional and trusted warehousing companies only.

When pondering on the lessened role of field warehousing in the US, it should be borne in mind that this security device - primarily the institutionalized variant - performed two economically quintessential functions on the market: policing of the collateral and provision of public notice about the security interest (i.e., a perfection method). As with the advent of the UCC perfection by way of simplified and cheap filing became a possibility, field warehousing remained a service worth paying for only in situations where policing of the collateral remained a problem. It follows from this that in jurisdictions where no cheap filing or registry for security interests is at place, field warehousing would play a comparably much more important role.

Even if to a significantly lower extent, however, field warehousing has remained an efficient collateral policing (control) device even in the US (Skilton 1961: at 222). notwithstanding the introduction of the floating lien by the UCC. The very essence of the continuedly valuable services of the field warehouseman is the skill of policing of inventory (Skilton 1961: at 251); ${ }^{127}$ or "his double-barreled guarantee of the collateral, both as policeman and as assumer of risks". ${ }^{128}$ This used to be and remains its main and unique addendum over other non-possessory security devices on inventory (i.e., factor's lien, trust receipts, chattel mortgage, conditional sales and consignment) not "supply[ing] a lot of controls, [that are otherwise] backed up by the responsibility of the warehouseman" (Skilton 1961: at 435-436). ${ }^{129}$

Admittedly idiosyncratic to the US yet the peculiar interplay of courts and the innovating warehousing industry deserves also attention. As it was hinted at, the

126 As Gilmore put it: "[i]n 1960, six large companies, five national and one regional, operated 95 percent of the six thousand field warehouses estimated to be in use; the largest of the six the Lawrence Warehouse Company was thought to control about half the market, both in the number of warehouses and in the volume of inventory for which warehouse receipts were issued."

127 As Skilton put it "[Albeit] [s]ome of the larger banks have commodity loan departments with people knowledgeable in the fluctuations of inventory values, but few are equipped to police inventory. The field warehouseman offers this service."

128 See Yale 1960 Comment: $I d$. at 708.

129 See 436. 
institutionalization of field warehousing was a positive factor for courts in deciding field warehousing cases and legitimizing it. The industry's task was "to strive for maximum assurance that [the field warehouse's] possession will be respected by courts, through punctilious procedures designed to give the best possible picture of possession" (Skilton 1961: at 246). This went hand in hand with the concentration of the industry shrinking eventually only to those who could perform arrangements impeccably something similar to the Benedict Ritual in the context of receivables financing. By the mid- $20^{\text {th }}$ century the industry has become "dominated by a few experienced firms whose familiarity with the requirements and the methods of satisfying them [made] non-compliance unlikely." 130 As a result attacks on the validity of field warehousing have almost disappeared by the $1960 \mathrm{~s}$ though also because bankruptcy trustees were too disinclined to challenge such field warehousing arrangements and field warehousing companies were prone to settle out of court "primarily to keep the confidence and goodwill of the banking community, on whom they depend[ed] for business, but also to prevent unfavorable precedents." 131 Institutionalization, in other words, was the way to win the trust of courts and of banks.

The other crucial lesson that ensues from the above, though primarily visible from the US and Hungarian experiences, is that the token of successful field warehousing is devising and applying of effective, constantly improving policing techniques. Skilton was right stressing that field warehousing should be perceived as a 'control device' (Skilton 1961). ${ }^{132}$ Technology obviously plays a role in this respect yet it is much more than that. Banks, namely, should devise and learn to the level of routine how to police their debtors and the field warehousing companies (Skilton 1961: at 267-268; 133 an expertise that cannot be substituted by registration (filing) or other potentially exploitable additional safety devices (Skilton 1961; Lloyds of London. Id. footnote 79, at 256; Gilmore 1965). ${ }^{134}$ On the other

130 See Yale 1960 Comment: Id. at 675.

131 Id. at $675-676$.

132 Skilton's long article devoted to field warehousing is clearly one of the seminal and most complete accounts of the US history of this peculiar device. Yet he himself hesitated which aspect of field warehousing should be given priority, the financing or the control aspects, when he stated that "This article could be entitled: Field Warehousing as a control device." See Skilton 1961: 222. Yet he properly stressed that "The procedures and practices of field warehousing [...] are not only designed to create an effective security device from a legal standpoint, but also to police the inventory, and keep it from being dissipated by the borrower." Id. at 222.

133 Skilton speaks of "systemic operations to double check the activities of the custodian" from reviewing his reports, on the spot checking to surprise visits to the field warehouse. He adds though that "[i]deally, ... the financier should make his own independent investigations [as well]".

134 This may include bonding both of the custodian (typically the employee entrusted with the operation of the warehouse) and of the warehouse companies themselves for the benefit of depositors. Two related caveats ought to be mentioned. Skilton warned that " $[a]$ prospective lender upon field warehouse receipts should not place blind reliance upon state bonding [which may but must not mean much] as bonding requirements are often low [and] [o]ften they relate to storage capacity and not to the value of products." See Skilton 1961: at 256. He also mentioned that national field warehouses, at least in those days, frequently used bonds issued by Lloyds of London. Id. footnote 79, at 256.

Gilmore warned of something else that "the presence of a bonding company as a temporary loss-bearer does nothing to solve the problem of ultimate liability; the underwriter of the bond will naturally look around, armed with the trusty weapons of subrogation and assignment, for someone who, on principles of fault, 'ought' to bear the loss." See Gilmore 1965: § 6.2., at 154. 
hand, lenders also should worry about the employed release procedures (Gilmore 1965) ${ }^{135}$ or the selection of their custodians and eventually all the steps necessary for erecting of a proper field warehouse.

The fallacy is that policing is not a statutory requirement since the enactment of UCC Article 9 and thus nothing in the text of the Article itself apart from a brief subsection ${ }^{136}$ conspicuously warns of the importance of policing. This is something presumed in developed systems, a natural corollary of banking and utilization of non-possessory or constructive possession-based security devices. Although the Official Comment and Gilmore mention obiter that policing remains important notwithstanding that it is not required by UCC Article 9 itself, such caveats are not heeding in modern times. To realize that there is a significant level of truth in this train of thought suffices to point to the fact that US secured transactions related casebooks tend not to reproduce the Benedict $v$. Ratner case. As a result, the scrutiny of contemporary text and casebooks would hardly reveal anything about the role and importance of policing to lawyers and reformers coming from systems with rudimentary secured transactions. Moreover, the technique of policing cannot be learned either from the text of UCC Article 9 itself, which otherwise has served as the primary source of inspirations for most of international reform projects during the last few decades.

\subsection{The English Perspective}

As the case of field warehousing proves, comparative law is often practice-driven or driven by the interests of affected power groups and in the lack of concrete real life problems attention tends to bypass otherwise legitimate legal issues. As field warehousing has failed to emerge in the UK, not more than a few lines of glosses have been devoted to it in the literature. Consequently, one may legitimately speculate that the English tale on field warehousing has remained unexplored which is not a problem in itself until English law with its incomplete narrative is offered to emerging markets without mature industries.

One must admit, however, that the juxtaposition of field warehousing and floating charge (lien) is primarily due to the insistence of English scholars who argue that the former has not emerged in their country because of the benevolent view of courts to floating security. In other words, the simplified message inherent in this view is that field warehousing is the imperfect substitute of the English floating charge and as now even the

135 This follows from the In Re United Wholesalers, Inc. 274 F.2d 316 ( $7^{\text {th }}$ Cir. 1960), in which then a novel type of the so-called 'secured distribution agreement' was at stake "chicken-wired enclosure [with goods, refrigerators and air conditioners] readily available for ... the salesman to display and offer for sale to ... customers." See Gilmore 1965: § 6.8.1., at 186. The essence is, however, Gilmore's caveat that the lesson to be drawn from the case is that "field warehouse companies and lenders [...] will be well advised to tighten up on their release procedures." See Gilmore 1965: § 6.8.2., at 193.

136 Section 9-205(b), which reads: "[Requirements of possession not relaxed.] This section does not relax the requirements of possession if attachment, perfection, or enforcement of a security interest depends upon possession of the collateral by the secured party." The Official Comments thereto are already clearer yet are only comments not necessarily consulted by foreign lawyers looking for explanations related to a complex subject. Yet the text deserves to be quoted: “... nothing in this section prevents the debtor and secured party from agreeing to procedures by which the secured party polices or monitors collateral or to restrictions on the debtor's dominion. However, this Article leaves these matters to agreement based on business considerations, not on legal requirements." 
American system knows about the floating lien it is futile to waste ink and paper on a security device that is doomed to extinction. Unfortunately, the discourse on the topic ends at that point and no attempt seems to have been made to go any further.

Yet as the Hungarian developments prove the introduction of a common-law inspired floating security does not eliminate the need for fields warehousing; quite to the contrary. In Hungary, banks have found in field warehousing their savior security device for agricultural financing when a local version of floating charge was available from 1996 on. Banks did not see in the field warehousing the alternative of floating lien but the needed control device; a substitute for the imperfect policing methods employed by banks. This lead to an environment much more resembling that of the US than that of the UK not knowing about this specific device. It is thus legitimate to conclude that field warehousing is much more than the substitute of the floating charge, it performs more functions and thus it makes sense for emerging systems to study the related US experiences.

Turning to the other side of Janus: while English law properly directed attention to the touching points that exist between field warehousing and floating lien, it has failed to answer what substitutes the control function of field warehousing in English law? While admittedly this is a legitimate question if raised by systems looking for the right models, one may speculate that this unexplored niche of English personal property security law may offer as well some hereinbefore unknown advantages for some segments of the local industries. Part of the answer presumably rests on the high respect to law and contracts, the existence of a highly professional class of receivers for enforcement of floating charges and government subsidy programs to make financing easier. However, each of these partial substitutes has long been known also in the US, irrespective of which field warehousing has not disappeared. Moreover, government support to financing agriculture has long been known also in Hungary notwithstanding of which field warehousing was resorted to by commercial banks at such a scale that could legitimately speak of one of the booming industries. In sum, it is legitimate to suspect that some elements of the mosaic are missing and English scholars still owe the answers not just to the inquiring emerging systems but also to themselves.

\subsection{The Hungarian and the Perspective of Emerging Markets}

Looking at English law, one may speculate that besides the early recognition of the floating charge and of its agricultural kin in 1928 could not be the only reason for the lack of field warehousing. The same doubts may be raised also with respect to Australian, Canadian laws or those of New Zealand notwithstanding the changes that ensued after the reform of their personal property security laws. Obviously the key to this query is not dependent on a single factor but is made of more less fathomable elements, some of which could be identified if we identify the differences that exist between Hungary (or emerging markets) and these jurisdictions. Four interlinked factors should be commented upon in turn.

The first relates to the differing levels of the rule of law. Albeit no simple formula exists for determining what the components of the rule of law are, the two commonly subscribed elements of relevance are the embeddedness and respect of law by participants of the market and the efficiency of courts. If the creditor knows that in a given jurisdiction contractual partners relatively easily may disregard their obligations, among others, because the only remedy for that is resort to courts and litigation lasting for years, then the costs corollary to policing debtors by way of field warehousing may be tolerable. It seems rational even to conclude that the lower the level of the rule of law, the bigger the need and utility of 
field warehousing in a country. Yet as the juxtaposition of UK and US two undoubtedly high rule of law jurisdictions proves the co-existence of high level of the rule of law and field warehousing are not necessarily mutually exclusive. This makes the quest for further explanations a matter of necessity.

A variation on the theme of inefficient courts is the second factor: the lack of self-help repossession in Hungary and typically in all systems belonging to the civilian legal tradition. This powerful tool allowing secured creditors to promptly react to the frauds of debtors at an early stage presumes some form of monitoring by secured creditors an incentive the intensity of which is considerably lower (if existent at all) in civilian systems. To this one should also add the deterrent effects self-help has on debtors. Given monitoring in general (i.e., not only related to field warehousing) was the subject matter of hot debate in the 1980s (the Kripke versus Jackson \& Kronman debate), here one should add that the debate departed and applied entirely only to the US. Once faced with the problems corollary to the enforcement of security interests in emerging markets, one could better see how quintessential it is notwithstanding that presuming that all "managers [in emerging systems] will misbehave [and] divert and misappropriate as much of firm resources from other owners and creditors as possible" would be equally erroneous (Kripke 1985: at 966 et seq.).

The third point of difference also relates to enforcement though only of floating types of securities. Namely, to most civilian systems private receivers who normally enforce these comprehensive securities are essentially still foreign, non-existent or the development of the industry is in its infancy. The lack of private receivers is a problem because the enforcement of floating securities to certain extent the functional alternatives of the field warehousing is problematic and unpredictable. Even though the receivers come into picture solely after default, or when fraud or other reasons of default have become known and not right from the moment the transactions came into being, the threat that professionals may enter the scene without court involvement obviously influences the behavior of debtors.

Finally, perhaps the most unfathomable are the know-how acquired by the participants of commercial life in the developed common law systems during the almost two-century-long evolution of secured transactions laws. As opposed to civilian laws, in these systems security devices on personal property have been subjected to registration as a rule. Consequently, for almost two centuries participants of the market have been forced to learn not just that registration is a must but that checking the registries and conducting further inquiries about the debtor and the collateral is important as well. Undoubtedly, this foundation was needed for the introduction of the notice-filing system in the US, something that is hardly imaginable in civilian systems in which registration of liens on movables was unheard of until the arrival of common law-inspired secured transactions reforms by the end of the $20^{\text {th }}$ century. This also affects the strategic behavior of debtors who know that the average financier will, at least, check what has been registered or filed.

Put simply, during a decade or two this know-how cannot be learned adequately, as for example the experiences from Hungary show, even by banks and the industry. Creditors do not know how to read the registries and what additional checks should be contracted for. This is a crucial distinguishing factor applicable to civil laws and emerging systems where consequently field warehousing must play a considerably more important role, both as a perfection and as an efficient policing method. In other words, one should not reckon with the extinction of field warehousing because of the introduction of a UCC Article 9-type simplified notice-filing, or other registration system - similarly to the post-UCC gradual decline of field warehousing after the UCC in the US. Rather, field warehousing, presumably with features somewhat different from the ones that used to be known in the US, should be looked upon as an important cog-wheel desperately needed in emerging systems. 


\subsection{The Broader Pragmatic Picture: The Planned EUUS Free Trade Agreement}

At the moment little is known about the contents of the Agreement (Emmott 2013); moreover it is uncertain whether it will materialize, at all. Yet as access to financing by small, mid-scale and agricultural enterprises is an issue on both sides of the Atlantic (and beyond) (Nwogu 2012: note 57, at 22) ${ }^{137}$ though the problem seems to be more acute in Europe for the still unfolding sovereign debt crisis. Exactly because of that upgrading and harmonization of secured transactions law might be one of the methods to enhance the free flow of capital across borders. True, this is primarily the issue of whether rapprochement along the lines of the comprehensive and unitary system of UCC Article 9 could be effectuated and not something limited to field warehousing only. However, a major advancement in this respect could become also a springboard for internationally oriented companies offering also services of this sort. As Book IX of the DCFR rests essentially on identical building blocks as UCC Article 9 - a de lege ferenda document expressing what leading scholars think of what Europe should do - it would be mistaken to think that this idea is sheer utopia.

\subsection{The Ultimate Lessons}

Surprising as it may turn out to be for US scholars, field warehousing has survived its subsuming under the UCC Article 9 umbrella. In new forms, adapted to the changed economic conditions and needs, it resurrected even if its popularity fails to reach the heights of the earlier glory days. The prophesy of Dolan made in 1991 thus seems to have materialized as, notwithstanding the predictions that "field warehousing is largely a thing of the past," it proved to be the concrete materialization of the tendency of commercial practices "to reappear at the very time academics pronounce them finished" (Dolan 1991: at 221). The recent US experiences illustrate also how flexible and many-faced this device is; its metamorphosis into the more complex set of 'collateral certification' services or the derivatives-linked 'commodity purchase transactions (REPOs).'

The other important lesson is that the belief that perfection is a panacea not just to the ostensible ownership (false wealth) problem central to secured transactions law but also to the fraud in law doctrine - is mistaken. In other words, provision of public notice on the existence of the security interest does not exclude the need for policing of the collateral, though it obviously mitigates the risk of fraud. Consequently, until there is a market for professional policing of the inventory-collateral, there will be also a need for the services of institutionalized field warehousing companies.

To what extent do the English floating charge and its kin fill the gap in economies not knowing of field warehousing remains a mystery; a mystery that should be illuminated by English lawyers. Until this cognitive vacuum is filled, emerging markets modeling themselves after English law should bear this limitation in mind. The same caveat applies also to the many international projects that forget to warn the recipients that a whole distinct business model can thrive - essentially invisibly - based on the few possessory pledge and constructive pledge, or pledge by bailment provisions; be it a civil or a common law system.

137 In Nigeria, thanks to the innovativeness of banks, resort has been made to this security device as well, though under the specific designation of 'tripartite warehouse facility.' See Nwogu 2012. Warehouses are licensed and thus monitored by the Abuja Securities and Commodities Exchange. Website at < http://www.abujacomex.com/ >; last visited on 23 March 2014. 
Hungary, the post-Yugoslav successor states and other systems in which field warehousing is a new-comer, should be looked upon as unexplored treasury boxes with numerous surprises for comparative legal scholarship. These systems should, instead of experimenting and making their own businesses, pay the price of mistakes of legal engineering with field warehousing, realize that it does pay to consult more advanced systems; including the realization of the inherent limits of the device. As hopefully properly showed in this paper, the key takeaway for reform systems is the realization that the token of field warehousing's success is exactly resort to what comparative law could offer, English and US scholars should realize that they owe answers to the queries raised herein.

\section{REFERENCES}

American Law Institute \& the Uniform Law Commission (1999): Revised Article 9 (1999) Revisions - Official Comments. United States, ALI \& ULC.

Bahaa Ali, El-Dean (2002): Privatization and the Creation of a Market-Based Legal System - the Case of Egypt. Leiden, Brill.

Baird, D. G.-Jackson, T. H. (1983): Possession and Ownership: Examination of the Scope of Article 9. Stanford Law Review 35 (2): 175-292.

von Bar, Ch.-Clive, E. (eds.) (2010): Principles, Definitions and Model Rules of European Private Law Draft Common Frame of Reference - Full Edition. Oxford, Oxford Press.

Barnes, R. L. (1988): Field Warehousing Cattle and their Sale on Recognized Markets. Journal of Agricultural Taxation \& Law 9: 337-352.

Brown, D. (2010): The New Zealand Personal Property Securities Act 1999. In: John de Lacy J. (ed), Personal Property Security Law Comparative Perspectives. London, Routledge-Cavendish.

Budd, N. (1995): General Description and Background of Field Warehousing. International Business Law, March 1995 issue: 120.

Comment (1960): Financing Inventory through Field Warehousing. Yale Law Journal 69 (4): 663708.

Dolan, F. J. (1978): The Uniform Commercial Code and the Concept of Possession in the Marketing and Financing of Goods. Texas Law Review, 56 (7): 1147.

Dolan, F. J. (1991): Uniform Commercial Code - Terms and Conditions in Commercial Law. BostonToronto-London, Little, Brown \& Co.

Duggan, A.-Brown, D. (2012): Australian Personal Property Securities Law. Australia, LexisNexis.

Dundas, H. R. (2013): An Outsider Looks in: Swiss Jurisprudence in Arbitration Cases - An Important Contribution to the Arbitral World. Arbitration, 79 (1): 89-97.

Ellinger E. P. (2003): Trust Receipt Financing. Journal of International Banking Law and Regulation, 18 (8): 305-310.

Ellinger, E. P.-Lomnicka, E.-Hooley R. (2006): Ellinger's Modern Banking Law. $4^{\text {th }}$ ed., Oxford Univ. Press.

Emmott, R. (2013): EU Trade Chief Hopes to Clinch U.S. Trade Deal by Late 2014, Reuters, available at < http://uk.reuters.com/article/2013/02/27/us-euro-summit-trade-idUKBRE91Q0QM20130227>.

Friedman, D. M. (1942): Field Warehousing. Columbia Law Review 42 (6): 991-1013.

Frisch, D. (2001): Revised Article 9: A Primer for the General Practitioner. University of Richmond Law Review, 35 (Nov.): 813.

Gamble, R. (2009): Developing View of a 360-Degree Credit Risk [Company Overview - Microsoft Corp.]. Treasury \& Risk, (July/August 2009 issue), electronic paper downloadable from $<$ http:// www.thefreelibrary.com/_print/PrintArticle.aspx?id=207324727>.

Garner, B. A. (editor in chief) ( $3^{\text {rd }}$ reprint, 2001): Black's Law Dictionary. $7^{\text {th }}$ ed., St. Paul, West.

Gibb, I. D. M. (1968): The Farm Management Loan as it Relates to Commercial Agriculture (Univ. of Manitoba, Febr. 1968) (master's thesis).

Gilmore, G. (1965): Security Interests in Personal Property. Boston \& Toronto: Little, Brown and Co. 
Golob, P.-Farrell, G.-Orchard, J. E. (eds) (2002-2004): Crop Post Harvest: Science and Technology, vol. I Principles and Practice. Oxford-Greenwich, Blackwell.

Gottlieb, S. (1978): Section 9-307(1) and Tanbro Fabrics: A Further Response. Business Lawyer, 33 (4): 2611-2615.

Gretton, G. L. (2003): Reception without Integration? Floating Charges and Mixed Systems. Tulane Law Review, 78 (1-2): 307-434.

Höllinger, F.-Rutten, L.-Kiriakov, K. (2009): The Use of Warehouse Receipt Finance in Agriculture in Transition Economies. Washington D.C.-London, World Bank-EBRD-FAO (Food and Agricultural Organization of the United Nations) publication.

Interview with an MKB Bank director (2010): Gazda-Praktikum issue of 30 Sept. 2010 available at $<$ http://saccer-ptipti.blogspot.hu/2010/09/kozraktarozas.html >.

Jacoby, H. N.-Saulnier, R. J. (1944): Financing Inventory on Field Warehouse Receipts. Electronic paper downloadable at $<$ http://www.nber.org/chapters/c4020.pdf $>$.

Kelényi, Zs. (1994): A közraktározás hazai jogszabályi háttere (The Hungarian Law on Warehousing). Kereskedelmi Jogi Értesitö, 1994 July-Aug.: 7-10.

Kershen, D. L. (1994): Comparing the United States Warehouse Act and U.C.C. Article 7. Creighton Law Review, 27 (3): 735-772.

Kohn, M. R. (2001): Study Concerning a Possible Convention on Inventory Financing. The Secured Lender, 57 (3): 34-42.

Kripke, H. (1977): Should Section 9-307(1) of the UCC Apply against a Secured Party in Possession. Business Lawyer, 33 (Nov.)

Kripke, H. (1985): Law and Economics: Measuring the Economic Efficiency of Commercial Law in a Vacuum of Fact. University of Pennsylvania Law Review 133 (June): 929-985.

Lacy, Ph. T. (1990): Conflicting Security Interests in Inventory and Proceeds under the Revised Article 9 of the Uniform Commercial Code. South Carolina Law Review 41(Winter): 247-457.

Lazere, M. R. (1968): Commercial Financing. New York, Ronald Press.

LeDain, G. E. (Spring 1956): Security upon Movable Property in the Province of Quebec. McGill Law Journal 2 (2): 78-113.

LoPucki, L. M.-Abraham, A. I.-Delahaye, B. P. (2013): Optimizing English and American Security Interests. Notre Dame Law Review 88 (4): 1785-1864.

Lurie, B.-Pope, R. (2008): The Long-Forgotten Bonded Field Warehouse Making a Comeback? The Secured Lender 64 (Nov): 74-76.

Lwowski, H-J.-Tetzlaff, Ch. (2008): Münchener Kommentar Insolvenzordnung. 2nd ed., Munich, Beck.

MacDonald, R. A. (1984): Inventory Financing in Quebec after Bill 97. Canadian Business Law Journal 9: 153-179.

McGuire, J. T. (1974): The Impact of the UCC on Field Warehousing. Uniform Commercial Code Law Journal 6: 267-283.

McKendrick, E. (ed.) (2010): Goode on Commercial Law. $4^{\text {th }}$ ed., London, Penguin.

Minty, M. L. (1930): The Agricultural Credits Act, 1928. Economic Journal 40 (June): 249-258.

Népszabadság [no author indicated] (2010): Ezer sebböl vérzik a közraktározás [Public Warehousing Bleeding from Thousand Wounds]. Budapest, Népszabadság Online, 15 Nov. 2010 issue, available at $<$ http://www.trademagazin.hu/piaci-hirek/ezer-sebbol-verzik-a-kozraktarozas.html >.

Nwogu, T. (2012): Secured Transactions Laws of Nigeria and Cameroon through the Lens of Article 9 of the Uniform Commercial Code of the United States of America, doctoral (S.J.D.) thesis defended at Central European University, Budapest.

Permanent Editorial Board for the Uniform Commercial Code

Rogers, J. E. et al. (1994): Secured Financing of Personal Property in Mexico: A Panel Discussion. U.S.-Mexican Law Journal, 2 (Symposium issue): 149.

Rutberg, S. (1994): The History of Asset-Based Lending. United States, the Commercial Finance Association.

Saskatchewan Heritage Foundation, Saskatchewan Grain Elevators - A Brief History of the Grain Handling Industry (2006); available electronically at $<$ http://www.pcs.gov.sk.ca/ GrainElevatorStudy $>$. 
Scottish Law Commission's Discussion Paper No. 151 on Moveable Transactions (2011).

Skilton, R. H. (1961): Field Warehousing as a Financing Device. Wisconsin Law Review (1961): Part I 221-276 and Part II 403-438.

Summers, R. (1963): Security Interests in a Retail Merchant's Inventory: California Amends the Uniform Commercial Code. Stanford Law Review 16 (3): 149-159.

Szász, S. (1994): A közraktározás története (The History of Warehousing in Hungary). Kereskedelmi Jogi Értesitö, July-Aug.: 5-7.

Szladits, K. (1942): Magyar magánjog - Dologi Jog [Hungarian Private Law - Property Law]. Budapest, Grill Károly Publishing Co.

Tajti, T. (2002): Comparative Secured Transactions Law. Budapest, Akadémiai Kiadó.

Tajti, T. (2013): Post-1990 Secured Transactions Law Reforms in Central and Eastern Europe. Szeged, Szegedi közjegyzöi közlöny 2 (2): 18-26

UNCITRAL (2010): Legislative Guide on Secured Transactions. New York, United Nations Commission on International Trade Law.

UNCTAD (2009): Review of Warehouse Receipt System and Inventory Credit Initiatives in Eastern \& Southern Africa. Geneva, United Nations Conference on Trade and Development.

UNIDROIT (2012): Colloquium on "Promoting Investment in Agriculture: Private Law Aspects." Rome, International Institute for the Unification of Private Law. Uniform Law Review, XVII (1/2).

Vaughn, M. J. (1967/68): Warehousing Security Transactions: Progeny of Twyne's Case. Baylor Law Review, 20(1): 1-24.

Wappett, C. (2012): Essential Personal Property Securities in Australia. Australia, LexisNexis \& Butterworths.

Winship, P. (1998), Selected Security Interests in the United States. In: Norton, J. and Andenas, M. (eds): Emerging Financial Markets and Secured Transactions. Leiden: Kluwer Law International, 273.

White, J.-Summers, R. (2010): Uniform Commercial Code. $6^{\text {th }}$ ed., St. Paul (US): West, $\S 23-4$, at 1194.

Wood, Ph. R. (2007): Comparative Law of Security Interests and Title Finance. London, Sweet \& Maxwell.

Wood, Ph. R. (2008): Law and Practice of International Finance. London, Sweet \& Maxwell.

Ziegel, J. S. (1963): The Legal Problem of Wholesale Financing of Durable Goods in Canada. Canadian Bar Review 41 (4): 54-112.

Ziegel, J. S.-Geva, B.-Cuming, R. C. C. (1995): Commercial and Consumer Transactions Cases, Text and Materials. Toronto, Emond Montgomery Publishers.

Ziegel, J. (2010): A Canadian Academic's Reactions to the Law Commission's Proposals. In: de Lacy, J. (ed.): Personal Property Security Law Comparative Perspectives. London-RoutledgeCavendish. 